\title{
WPŁYW WARUNKÓW ATMOSFERYCZNYCH NA DZIAŁANIA 1 DYWIZJI PIECHOTY IM. TADEUSZA KOŚCIUSZKI W BITWIE POD LENINO*
}

\begin{abstract}
Streszczenie. Bitwa pod Lenino trwała od 12 do 17 października 1943 r. W ciągu pięciu dni walk sowiecka 33 Armia podjęła szereg prób przełamania niemieckich pozycji nad rzeką Miereją. W trakcie pierwszych dwóch dni w bitwie wzięła udział polska 1 Dywizja Piechoty. W dotychczasowej historiografii bitwy zagadnienie wpływu warunków atmosferycznych na jej przebieg nie stało się przedmiotem naukowej analizy. Na podstawie nowych źródeł z archiwów niemieckich i rosyjskich możliwe stało się odtworzenie stanu pogody w okresie bitwy. $Z$ analizy danych tam zawartych wynika, że stosunkowo dobre warunki pogodowe lepiej wykorzystała strona niemiecka. Dowództwo 33 Armii nie potrafiło elastycznie reagować na zmianę pogody. W przededniu bitwy na stronę niemiecką przeszyła grupa dezerterów, którzy zdradzili termin natarcia. W efekcie Niemcy zgromadzili pokaźne siły lotnicze. Wykorzystując dogodne warunki pogodowe Luftwaffe walnie przyczyniła się do przesunięcia szali zwycięstwa pod Lenino na stronę niemiecką.
\end{abstract}

Słowa kluczowe: Lenino, warunki pogodowe, front wschodni, Armia Czerwona, Luftwaffe

W dniach od 12 do 17/18 października 1943 r. wojska Frontu Zachodniego Armii Czerwonej podjęły nieudaną próbę przełamania pozycji obronnych niemieckiej 4 Armii, osłaniającej od wschodu rejon Orszy z przedmościem na Dnieprze. Ze względu na przebieg wcześniejszych i późniejszych walk na kierunku Orszy zwrot zaczepny Frontu Zachodniego został określany mianem

* Artykuł powstał w wyniku realizacji projektu badawczego o nr 2017/27/N/HS3/02926 finansowanego ze środków Narodowego Centrum Nauki. 
drugiej orszańskiej operacji zaczepnej ${ }^{1}$. W polskiej historiografii wojskowej operacja ta identyfikowana jest jako bitwa pod Lenino 1 Dywizji Piechoty im. Tadeusza Kościuszki (1 DP)².

\section{Baza źródłowa}

Zagadnienie warunków meteorologicznych w okresie bitwy pod Lenino nie stało się dotąd przedmiotem pogłębionej analizy. Przeszkodą w naukowym ujęciu problemu był brak dostępu do materiałów źródłowych. Jako że pogoda nie była czynnikiem decydującym o przebiegu bitwy, za dostateczny uważano opis warunków meteorologicznych zaczerpnięty z lektury licznych wspomnień.

Brak materiałów źródłowych $\mathrm{z}$ danymi na temat pogody wynikał $\mathrm{z}$ tego, że 1 DP nie posiadała własnej służby hydrologiczno-meteorologicznej, takowa pojawiła się dopiero wraz ze sformowaniem 1 Armii Polskiej w ZSRS. Pierwsze meldunki pogodowe pochodzą z połowy lipca 1944 r. ${ }^{3}$ Ponadto $w$ okresie bitwy pod Lenino dowództwo 1 DP nie otrzymało żadnych informacji dotyczących prognozowanych warunków atmosferycznych, które zachowałby się $\mathrm{w}$ materiale aktowym. $\mathrm{Z}$ tego powodu $\mathrm{w}$ dokumentach wytworzonych przez pododdziały i sztab $1 \mathrm{DP}$ pojawiają się tylko ogólnikowe informacje o pogodzie oparte na obserwacji wzrokowej: „Pogoda była bardzo dobra. Widoczność dobra. Wszystko to pozwalało przeprowadzić wszelki ruch i ześrodkowania tylko w nocy"4.

${ }^{1}$ D.M. Glantz, M.E. Glantz, Battle for Belorussia. The Red Army's Forgotten Campaign of October 1943 - April 1944, Kansas 2016, s. 14.

2 Wyjątek stanowi dwuczęściowy artykuł autorstwa Roberta Wróblewskiego, który jest próbą przedstawienia działań wojsk niemieckich w rejonie Lenino w całym okresie sowieckiej ofensywy. R. WRóblewski, Bitwa pod Lenino w niemieckich meldunkach, cz. 1, „Militaria XX Wieku” 2010, nr 6 (39), s. 58-69; IDEM, cz. 2, „Militaria XX Wieku” 2011, nr 2 (41), s. 54-64.

${ }^{3}$ Centralne Archiwum Wojskowe, Wojskowe Biuro Historyczne [dalej: CAW WBH], IX.4.45.38, S. GAĆ, Charakterystyka warunków klimatyczno-atmosferycznych za okres walk 1 AWP (15.07.44 r. - 30.04 .1945 r.) (referat materiałowy), k. 1-13; IDEM, Stan pogody na obszarze dziatań 1 Armii Wojska Polskiego w okresie od 15 lipca 1944 r. do 20 kwietnia 1945 r., [w:] Z zagadnień rozwoju ludowego Wojska Polskiego, red. J. Margules, Warszawa 1964, s. 252-272.

${ }^{4}$ CAW WBH, III-7-546, Opisanie operacyj po wsparciu natarcia 1-go pp 1-szym PAL na kierunku Lenino za okres 11.10 do 13.10 .43 r., k. 63. 
Uzupełnieniem tej luki były relacje oficerów i żołnierzy 1 DP. Lektura beletrystyki i wydanych drukiem wspomnień weteranów dostarcza licznych spostrzeżeń na temat pogody. Ich wspólną cechą są kwieciste opisy zjawisk atmosferycznych, za przykład może posłużyć następujący fragment: „Blady świt odsłaniał oszronione krzaki i ścierniska. Na lufach broni i przyrządach optycznych osiadła zimna powłoka rosy. Horyzont, jak okiem sięgnąć, zginął w niskich chmurach, wiszących szarym całunem na szerokim nieboskłonie. W polu widzenia pojawił się jesienny gość - coraz gęściejsza falująca mogła”’ Powyższy fragment, jak i wiele innych równie barwnych opisów, służył odwróceniu uwagi czytelnika od dramatycznego bilansu bitwy pod Lenino. Ponadto nadawanie edytowanym źródłom narratywnym cech utworu literackiego poszerzało grono czytelników, co sprzyjało mitologizowaniu bitwy pod Lenino.

Od czasów starożytnych prowadzenie działań wojennych uzależnione było od warunków pogodowych ${ }^{6}$. Wszystkie regularne armie walczące na polach II wojny światowej posiadały służby hydrologiczno-meteorologiczne. Nie inaczej było w przypadku Armii Czerwonej. Do zadań służby hydrologiczno-meteorologicznej należały: obserwacja i prognozy pogody; sporządzanie opisów klimatycznych obszarów przyszłych działań bojowych; zestawienie uwzględniające czas wschodu i zachodu słońca i księżyca; sporządzanie długoterminowych prognoz hydrologicznych na temat rzek, jezior, bagien oraz technicznych urządzeń wodnych na obszarze działań wojennych ${ }^{7}$. Realizacja powierzonych zadań odbywała się na podstawie pomiarów wykonywanych z wykorzystaniem polowego sprzętu meteorologicznego oraz danych przekazywanych przez instytucje państwowe.

W czasie bitwy pod Lenino 1 DP była podporządkowana dowództwu 33 Armii ze składu wojsk Frontu Zachodniego. Zarówno 33 Armia, jak i do-

${ }^{5}$ L. Dubicki, Salwy nad Miereja, Warszawa 1980, s. 62.

${ }^{6}$ Szerzej o wpływie pogody na działania wojenne na przestrzeni dziejów: E. Durschmied, Jak pogoda zmieniata losy wojen iświata, Warszawa 2017.

${ }^{7}$ Kadr dostarczał Wyższy Wojskowy Instytut Hydro-Meteorologiczny Armii Czerwonej zlokalizowany w Leningradzie, a następnie w Moskwie. Vide: W.N. Priamicyn, „Dat' $w$ WWS RKKA wysokokwalificyrowannych kadrow mietieorotogow". Podgotowka wojennych gidromietieorotogow dla Krasnoj armii w 1930-1940-ch godach, „Wojenno-Istoriczeskij Żurnał” (В.Н. Прямицын, „Дать в ВВС РККА высококвалифичированных кадров метеорологов". Подготовка военных гидрометеорологов для Красной армии в 1930-1940-х годах, „Военно-Исторический Журнал”) 2017, N 17, s. $15-21$. 
wództwo frontu posiadały w swej strukturze oddziały służby hydrologiczno-meteorologicznej. Szefem oddziału hydrologiczno-meteorologicznego $33 \mathrm{Ar}$ mii był mjr inż. Aleksiej Rybinkow ${ }^{8}$, a Frontu Zachodniego - mjr inż. Aleksiej Safonow?

Efektem pracy oddziałów służby hydrologiczno-meteorologicznej 33 Armii i Frontu Zachodniego były prognozy pogody na kolejne dni działań bojowych, a także meldunki pogodowe zawierające bieżące informacje na temat warunków atmosferycznych. Wymienione źródła nie zachowały się w zasobie akt dowództw, co może sugerować, że po pewnym czasie były brakowane, niemniej ich treść znalazła się w meldunkach dziennych sztabu 33 Armii sporządzanych dla dowództwa Frontu Zachodniego.

Poza meldunkami dziennymi 33 Armii $^{10}$ interesujące w kontekście bitwy pod Lenino są meldunki dzienne 1 Armii Lotniczej (ALot), która wspierała walczące wojska z powietrza, a także dowództwa Frontu Zachodniego.

Meldunki dowództwa Frontu Zachodniego zawierają informacje na temat zachmurzenia i jego wysokości, wstępowania opadów, widoczności w ciągu dnia i nocy, kierunku i prędkości wiatru oraz temperatury powietrza. Ponadto w każdym meldunku znajdują się uwagi na temat stanu przejezdności dróg dla samochodów ciężarowych na trasach dofrontowych ${ }^{11}$. Pomimo że informacje zawarte w dokumentach Frontu Zachodniego są stosunkowo szczegółowe, należy z dużą ostrożnością odczytywać je w kontekście bitwy pod Lenino, gdyż dotyczą znacznie większego obszaru działań wojennych niż wąski pas natarcia 33 Armii.

Uzupełnienie danych zebranych przez sztab Frontu Zachodniego stanowią meldunki dowództwa 33 Armii. Każdy z nich składa się z kilku lub kilkunastu punktów. Informacje o pogodzie znajdowały się za każdym razem $\mathrm{w}$ przedostatnim punkcie, po informacjach dotyczących strat dziennych i przed opisem stanu łączności. Dane obrazują stan pogody w okresie od godziny 22.00 dnia poprzedniego do 22.00 dnia bieżącego. Meldunki dowództwa 33 Armii w części poświęconej pogodzie zwierają następujące informacje: zachmurzenie,

${ }^{8}$ Centralnyj Archiw Ministierstwa Oborony (Центральный архив Министерства Обороны), [dalej: CAMO], fond (ФонА) 208, opis (Опись) 2511, Deło (Аемо) [dalej: D.] 2558, k. 432.

9 Ibidem, k. 389.

10 Także dokumenty wytworzone przez dowództwa sąsiadów 33. Armii, a mianowicie 21 i 49. Armii, również są wartościowym źródłem, gdyż obie armie prowadziły działania w tym samym rejonie.

${ }_{11}$ CAMO, fond 208, opis 2511, D. 2545, Opierswodki sz. FZ (Оперсводки ш. Ф3), k. 45-71. 
występowanie mgieł i opadów, widoczność, minimalna i maksymalna temperatura powietrza, kierunek i prędkość wiatru. Poziom zachmurzenia podawany był za pomocą opisu słownego ${ }^{12}$.

Szczególnie interesujące są informacje zawarte w aktach dowództwa 1 ALot, co wynika ze specyfiki potrzeb lotnictwa wojskowego. Meldunki dowództwa armii były składane o godzinie 23.00 i dotyczyły stanu pogody w nocy przed świtem, rano i po południu bieżącego dnia ${ }^{13}$. W porównaniu z meldunkami dowództw 33 Armii, zawierają więcej szczegółowych danych na temat gęstości i wysokości pokrywy chmur, widoczności, występowania mgieł i opadów, ale nie ma w nich pomiarów temperatury powietrza. Zachmurzenie podawane jest w 10-stopniowej skali dekanowej, która w Polsce była używana przed 1989 r. ${ }^{14}$ Pojawiają się w nich informacje o rzadkich zjawiskach atmosferycznych, takich jak np. mgła radiacyjna ${ }^{15}$. Meldunki meteorologiczne 1 ALot dotyczą obszaru znacznie większego niż w przypadku armii wojsk lądowych, niemniej ich wartość polega na tym, że można je odnieść także do działań lotnictwa niemieckiego ${ }^{16}$.

Nie wszystkie meldunki wymienionych powyżej związków operacyjnych są kompletne, niekiedy brakuje w nich któregoś z elementów. Istnieją różnice 1-2 stopniowe pomiędzy wynikami pomiarów temperatury powietrza w poszczególnych meldunkach. Duże rozbieżności występują w przypadku danych dotyczących kierunku i prędkości wiatru. W żadnym z meldunków nie ma informacji na temat ciśnienia powietrza.

Uzupełnieniem meldunków sowieckiej służby hydrologiczno-meteorologicznej są źródła znajdujące się w zasobie Bundesarchiv Militärarchive w Freiburgu im Breisgau. W aktach XXXIX KPanc i jednostek podległych nie zachowały się osobne meldunki wytworzone przez niemieckie służby badające stan pogody na potrzeby bieżącej pracy sztabów. Niemniej, podobnie jak w przypadku dokumentów sowieckich, informacje na ten temat zawarte są w meldunkach

12 CAMO, fond 388, opis 8712, D. 429, Opierswodka sz. 33. Armii (Оперсводка ш. 33. Apмии), k. 68-92.

13 CAMO, fond 290, opis 0003284, D. 0296, Opierswodki sz. 1 WA (Оперсводки ш. 1. BA), k. $140-154$.

14 Współcześnie stosuje się skalę oktanową.

15 Mgła, który powstaje nad ranem, na skutek nocnego wypromieniowania ciepła, wytupująca tylko przy gruncie lub do wysokości kilkuset metrów. CAMO, fond 290, opis 0003284, D. 0296, Opierswodka N² 282 sz. 1 WA, k. 150.

16 CAMO, fond 290, opis 0003284, D. 0296, Opierswodki sz. 1 WA, k. 140-154. 
dziennych, dziennikach działań bojowych (Kriegstagebuch - KTB) lub znajdują się w załącznikach do sprawozdań. Charakterystyka pogody pojawia się przy codziennych wpisach w KTB niemieckich dywizji (95, 252 i 337 Dywizja Piechoty) uczestniczących w walkach pod Lenino i znajduje się w osobnej rubryce „Wetterlage” ${ }^{17}$. Dane tam zawarte są bardzo ogólne, ograniczone do słownego opisu stanu zachmurzenia, widoczności oraz przejezdności dróg. Wpisy w KTB nie zawsze są kompletne, przykładowo w KTB 337 DP brak jest wpisu z dnia 4 października $1943 \mathrm{r}^{18}$ Wartościowej informacji na temat stanu pogody dostarcza załącznik nr 2 do KTB $95 \mathrm{DP}^{19}$, w postaci wykresu ukazującego wysokość temperatury w godzinach porannych, w południe i wieczorem, a także stanu zachmurzenia w ciągu października. Wartości temperatury powietrza niekiedy różnią się $\mathrm{w}$ stosunku do tych podawanych przez stronę sowiecką o $1-4^{\circ} \mathrm{C}$. Rozbieżność te mogą wynikać z różnic metodologicznych i praktyki pomiarów.

Ze względu na charakterystykę zadań realizowanych przez 1 DP oraz przebieg bitwy pod Lenino można wyodrębnić trzy okresy, w których pogoda wywierała określony wpływ na przebieg wypadków:

- 23 września - 11 października 1943 r. - marsz 1 DP w kierunku frontu i przygotowania do bitwy;

- 12-13 października 1943 r. - natarcie i walka 1 DP o wsie Trigubowa i Połzuchy;

- 14-17 października 1943 r. - dalszy przebieg bitwy pod Lenino, po wycofaniu 1 DP z pierwszej linii do odwodu 33 Armii.

Dane meteorologiczne dowództw Frontu Zachodniego, 1 ALot i 33 Armii z okresu od momentu podporządkowania 1 DP sztabowi 10 Armii Gwardii (AGw), a następnie 33 Armii oraz z bitwy pod Lenino zostały zestawione w postaci załącznika do artykułu.

17 Bundesarchiv-Militärarchiv (BArch-MA), RH 26-337/33; RH 26-252/106; RH 26-95/36.

18 BArch-MA, RH 26-337-33, KTB Nr. 5 der 337. ID, k. 8.

19 BArch-MA, RH 26-95/38, Anlagenband 2 zum KTB Nr. 5 der 95. ID. 


\section{Warunki atmosferyczne w czasie przemarszu 1 DP i w okresie przygotowania do natarcia pod Lenino (23 września - 11 października 1943)}

Do 23 września 1943 r. 1 DP pozostawała w rejonie Wiaźmy, kończąc szkolenie przerwane wyjściem z obozu pod Sielcami na terenie Moskiewskiego Obwodu Wojskowego. Późnym wieczorem 23 września 1943 r. 1 DP rozpoczęła marsz w kierunku zachodnim ${ }^{20} .1$ października 1943 r. 1 DP została oddana pod rozkazy dowództwa $10 \mathrm{AGw}$ ze składu Frontu Zachodniego ${ }^{21}$. W tym czasie pododdziały dywizji poruszały się wzdłuż szosy Moskwa-Smoleńsk-Mińsk. W podporządkowaniu $10 \mathrm{AGw}$ dywizja pozostawała do 7 października. Tego dnia 1 DP została oddana pod rozkazy dowódcy 33 Armii, którym był gen. Wasilij Gordow. Oznaczało to konieczność dokonania nagłej zmiany dyslokacji z pasa działania $10 \mathrm{AGw}$ na kierunku miasta Lady, do rejonu koncentracji 33 Armii pod Lenino. Po dwóch dniach marszu, 9 października, 1 DP skoncentrowana została w rejonie wsi Ladiszcze, Zachwidow, Budy, Pankowo. W nocy z 9 na 10 października poddziały1 DP zluzowały na linii frontu sowiecką 42 Dywizję Strzelców (DS), obejmując stanowiska pod Sysojewo i Lenino. Okres 16 dni od 23 września do 9 października 1943 r. upłynął na długim, bo liczącym $250 \mathrm{~km}$, marszu w kierunku linii frontu. Temperatura powietrza we wskazanym czasie, według meldunków Frontu Zachodniego wynosiła średnio: $5,85^{\circ} \mathrm{C}$ w nocy i $12,76^{\circ} \mathrm{C}$ w dzień, średnia za cały okres to $9,3^{\circ} \mathrm{C}$. Najzimniejsza była noc 6/7 października 1943 r., gdy temperatura spadła do $-2^{\circ} \mathrm{C}$, a najcieplejszym dniem był 26 września, kiedy to temperatura około południa wyniosła $20^{\circ} \mathrm{C}$. Na podstawie meldunków 33 Armii za okres 1-11 października średnia temperatura powietrza wynosiła $8,35^{\circ} \mathrm{C}$. Mimo że były to stosunkowo wysokie temperatury, wrażenie chłodu potęgował porywisty południowo-zachodni wiatr i opady atmosferyczne. W dniach 23-26 września zachmurzenie było duże lub całkowite. Od 27 września rozpoczęły się deszcze i mżawki, które towarzyszyły żołnierzom 1 DP do 7 października. Ponadto każdego dnia od początku do połowy października występowały poranne mgły i miejscowe zamglenia.

${ }^{20}$ CAW WBH, III-7-546, Rozporządzenie bojowe dla sztabu nr 05 z 23.9.1943 r., s. 8; Rozkaz bojowy nr 01 sztabu 1 PDP z 23.9.1943 r., k. 9; Rozkaz bojowy nr 02 sztabu 1 PDP im. T. Kościuszki z 23.9.1943 r., k. 10.

${ }^{21}$ CAW WBH, III-7-15, Dziennik działań bojowych 1 DP, k. 5. 
Okres przemieszczenia się 1 DP do strefy przyfrontowej zapisał się w pamięci żołnierzy jako niezwykle uciążliwy. Za przykład odczuwalnych warunków marszu mogą posłużyć relacje chor. Jana Fereńca z 3 pp i chor. Justyna Kwacza z 1 pp: „Marsz w kierunku frontu odbywał się w bardzo złych warunkach atmosferycznych. Bezustannie siąpił deszcz i dął przenikliwy silny wiatr co utrudniało i tak niełatwą drogę. Żołnierze byli wyczerpani, ale mimo to wykazywali ogromny hart ducha i wytrzymałość fizyczną"22.

„Wychodziliśmy na «Warszawskoje szose». Kto brał udział w tych marszach to pamięta, że były to niezwykle uciążliwe marsze. Maszerowało się tylko w nocy, często padały deszcze, ognia nie wolno było rozpalić, podczas marszu nocnego nie wolno było zapalić papierosa"23.

Wycofujące się oddziały niemieckie stosowały taktykę „spalonej ziemi”, podkładając ogień pod zabudowania na drodze odwrotu. W efekcie wzdłuż dróg prowadzących w stronę frontu mało było budynków, w których żołnierze mogliby schronić się przed wilgocią i zimnem². Pomimo złych warunków sanitarnych panujących w czasie marszu, w dniu 3 października, łącznie w 1, 2 i 3 pułku piechoty (pp) zachorowało 225 ludzi, tj. 2,57\% stanu etatowego tych pułków. Nie były to straty duże i nie uszczupliły one znacząco siły dywizji ${ }^{25}$.

Przybycie 1 DP w rejon wsi Budy, 9 października 1943 r., zbiegło się z wystąpieniem pierwszych nocnych przymrozków, co zostało odnotowane przez służby metrologiczno-hydrologiczne Frontu Zachodniego i $33 \mathrm{Armii}^{26}$. Pokrywa się to z opisami pogody zaczerpniętymi ze źródeł narracyjnych. Jako przykład może posłużyć relacja żołnierza, strz. Mikołaja Kałłaura z 3 pp: „Na wieczór zatrzymaliśmy się na łące koło miejscowości Krasatinka, gdzie stacjonowaliśmy od 6 do 11 października. Dnie były słoneczne, pogodne, sprzyjające działaniom lotnictwa zarówno z jednej, jak i drugiej strony. Za to noce były bardzo zimne. Występowały przymrozki, tak że nad ranem łąki pokryte były szronem. [...] Było bardzo zimno. Szczególnie marzły nogi, bo to ciągnęło od butów. Oczywiście nie rozbieraliśmy się i nie zdejmowaliśmy butów. Radziliśmy sobie w ten sposób,

22 J. FerenIEC, Jak zostatem żotnierzem. Wspomnienia Kościuszkowca, Warszawa 1995, s. 68.

${ }^{23}$ CAW WBH, IX.4.44.8, J. Kwacz, Wspomnienia z 1-go Pułku Piechoty, s. 3.

${ }^{24}$ R. Marchwicki, Strzępy wspomnień z Grodna, zestania i wojny, Warszawa 2004, s. 183.

25 CAW WBH, IX.4.44.2, L. Szenwalda, Kronika 1 DP, s. 47.

26 CAMO, fond 208, opis 2511, D. 2545, Opierswodka No 478 Sztaba FZ, k. 55; CAMO, fond 388, opis 8712, D. 429, Opierswodka N ${ }^{\circ} 480$ Sztaba 33. Armii, k. 78. 
że zdejmowaliśmy waciaki, które wydano nam pod płaszcz i wciągaliśmy sobie nogi, układając stopy z butami w rękawy, tak, że spaliśmy i mieliśmy ciepło jak w ulu"27.

Wprawdzie niskie temperatury stanowiły niedogodność dla żołnierzy 1 DP, to jednak nie był to czynnik obniżający gotowość bojową dywizji i powodujący straty. Żołnierze potrafili radzić sobie w zastanych warunkach, o czym świadczy cytowana powyżej relacja.

W odróżnieniu od żołnierzy, dowództwo 1 DP uważało warunki atmosferyczne za korzystne dla przebiegu przemieszczenia. Przez pierwsze trzy dni października 1943 r. niebo było całkowicie zasłonięte przez chmury, występujące na wysokości od $100 \mathrm{~m}$, widoczność zaś w różnych porach dnia wahała się od 2 do $10 \mathrm{~km}$. W sposób istotny utrudniało to prowadzenie nalotów bombowych z niskiej wysokości i loty rozpoznawcze niemieckiego lotnictwa ${ }^{28}$. Dostrzegało to dowództwo 1 DP, co wyraził gen. Zygmunt Berling słowami: „Pogoda, a raczej niepogoda, nam sprzyja. Chmury - to nasze najlepsze maskowanie. Deszcz stał się naszym chlebem codziennym"29.

W ciągu kolejnych dni, od 4 od 10 października, zachmurzenie było zmienne. Według danych zawartych w KTB niemieckiej 337 DP pogodnie było 6,7 oraz 10 października, pozostałe zaś dni były pochmurne. Mimo że warunki atmosferyczne stopniowo zmieniały się na korzyść lotów, to siły powietrzne obu stron nie przejawiały większej aktywności. Zadania realizowało jedynie lotnictwo rozpoznawcze. Ataki pojedynczych samolotów Luftwaffe na kolumny 1 DP zdarzały się rzadko i pozostały bez wpływu na przebieg marszu. Według danych dostarczonych przez służbę obserwacyjno-meldunkową pododdziałów Frontu Zachodniego w dniach 1-11 października liczba samolotolotów nieprzyjacielskiego lotnictwa nad pozycjami całego frontu wahała się od 4 do 56, wynosząc średnio 16 samolotolotów na dobę. Było to mało, biorąc pod uwagę,

${ }^{27}$ CAW WBH, IX.4.44.240, Płk. Kałłaur, Relacja uczestnika walk 3 Berlińskiego Pułku Piechoty 1 DP w czasie ostatniej wojny, s. 123.

${ }^{28} \mathrm{Na}$ temat wpływu warunków hydro-metrologicznych na operacje sił powietrznych vide: L. KALINowski, Meteorologiczne zabezpieczenie dziatań bojowych lotnictwa, „Zeszyty Naukowe Państwowej Wyższej Szkoły Zawodowej im. Witelona w Legnicy” 2017, nr 1, s. 185-195.

${ }^{29}$ Nie uchroniło to całkowicie 1 DP przed działaniami niemieckiego lotnictwa. 1 X 1943 r. nad kolumną 1 pp pojawił się samolot rozpoznawczy, lecący na stosunkowo niskim pułapie, co pozwoliło żołnierzom 2 batalionu na otwarcie ognia w stronę nieprzyjaciela. CAW WBH, III-7-558, Kronika 1 Dywizji Piechoty, s. 46, 52. 
że szerokość pasa działań Frontu Zachodniego w dniu 10 października wynosiła $170 \mathrm{~km}^{30}$. Nieduża aktywność Luftwaffe wprost wynikała z niedogodnych warunków atmosferycznych w okresie od 29 września do 3 października oraz występujących zachmurzeń w okresie późniejszym ${ }^{31}$. Okres jesienny w październiku i listopadzie nie sprzyja prowadzeniu działań wojennych na obszarze Białorusi i Rosji. Miesiące te są potocznie określane mianem „rasputica” (ros. pacnymuua) i cechują się wstępowaniem znaczących trudności w pokonywaniu dróg gruntowych. Poświadcza to przebieg działań wojennych Wehrmachtu w październiku $1941 \mathrm{r}$. Dwa lata później warunki o tej porze roku były równie niekorzystne. Jako że drogi o nawierzchni twardej były zarezerwowane dla sowieckich jednostek dostarczających zaopatrzenie w kierunku frontu, 1 DP musiała przemieszczać się wzdłuż dróg nieutwardzonych. Według meldunków dowództwa Frontu Zachodniego utrudnienia dla transportu samochodowego na drogach gruntowych wstępowały we wszystkie dni pierwszej dekady października. Szczególnie źle prezentowały się drogi 7 i 8 października 1943 r., kiedy meldowano o błocie, koleinach i wybojach. Powodem takiego stanu dróg były deszcze i utrzymująca się duża wilgotność powietrza przy gruncie. Poczynając od 9 października do końca trwania bitwy pod Lenino, sytuacja panująca na drogach gruntowych uległa polepszeniu, a trudności w ruchu pojazdów mechanicznych występowały jedynie w lasach i obniżeniach terenu ${ }^{32}$.

Przy panujących warunkach drogowych wysoce problematyczny był ruch samochodów dywizji, co ilustruje relacja gen. Berlinga: „Wszelkie moje wyobrażenia o złej komunikacji doznały rewolucyjnego wstrząsu, na widok tego, po czym posuwał się nasz samochód. Powtarzam, posuwał się, bo o jeździe nie było mowy. Było to coś, co dałoby się porównać z księżycowym krajobrazem w miniaturze, zalanym przez powódź czepliwej, lgnącej do kół mazi i tworzącej z kół cztery nieokreślonego kształtu bryły, które nie wiadomo na zasadzie jakiego prawa fizyki zachowały zdolność toczenia się. [...] Oczywiście w tych

${ }^{30}$ CAMO, fond 208, opis 2511, D. 2588, Otczetnajaakarta (Отчетнаяакарта).

31 W większości były to samoloty rozpoznawcze Fw-189 lub starsze Hs-126, czasem osłaniane przez myśliwce Fw-190, CAMO, fond 208, opis 2548, D. 74, Dokład o bojewojdiejatielnosti WWS protiwnika i swoichsriedstw PWO wojsk ZapF za pieriod s 1 oktiabria po 1 nojabria 1943 goda (Аокмад о боевойдеятельности ВВС противника и своихсредств ПВО войск ЗапФ за периоА с 1 октября по 1 ноября 1943 года), k. 455, 471.

32 CAMO, fond 208, opis 2511, D. 2545, Opierswodki sz. FZ, k. 51-71. 
warunkach zawrotna szybkość $10 \mathrm{~km}$ na godzinę była szczytem umiejętności kierowcy. Wyobrażałem sobie jak na tej drodze musiała wyglądać dywizja! Ludzie, wozy, konie, sprzęt, samochody" ${ }^{33}$.

Pomimo wszechobecnego błota i kolein pododdziały 1 DP zdołały skoncentrować się na linii frontu przed rozpoczęciem bitwy. Mimo to stan sieci drogowej powodował dalsze trudności dla kolumn zaopatrzeniowych dywizji. Dnia 9 października 1943 r. gen. Berling wydał rozkaz bojowy nr 13, w którym zwracał szczególną uwagę na zabezpieczenie materiałowe i właściwe użytkowanie transportu konnego i samochodowego. Została ustalona górna granica ładowności do $400 \mathrm{~kg}$ na jeden wóz konny. Jednoczenie dowódca dywizji rozkazał: „otoczyć opieką konie ze względu na wielkie znaczenie dla transportu - drogi złe, a przed nami jeszcze jesienne słoty" 34 . Ponadto do zabezpieczenia przejezdności dróg dojazdowych wyznaczono część sił 1 batalionu saperów ${ }^{35}$.

Także pododdziały 33 Armii odnotowywały trudności wynikające z wpływu pogody na stan dróg gruntowych. Zabłocone ciągi komunikacyjne były powodem szybkiego zużywania się pojazdów mechanicznych, zwłaszcza tych produkcji sowieckiej. Problem ten meldowało dowództwo 48 Dywizji Artylerii Przeciwlotniczej, która miała zapewnić osłonę przed nalotami z powietrza dla pododdziałów 33 Armii. W efekcie usterek i trudnych warunków drogowych całkowicie zmotoryzowane pułki artylerii przeciwlotniczej nie zdołały przemieścić się na wyznaczone przed bitwą stanowiska ogniowe, pozostawiając za sobą od jednej do dwóch bateriii ${ }^{36}$.

Takich kłopotów nie odczuwała strona niemiecka. Z KTB 337 DP wynika, że w okresie 5-11 października 1943 r. drogi po niemieckiej stronie frontu były przejezdne. Różnicę w stosunku do danych pochodzących ze źródeł sowieckich można tłumaczyć gęstszą siecią drogową na tyłach niemieckiej $4 \mathrm{Armii}^{37}$.

33 Z. Berling, Przeciw 17 Republice, t. 2, Warszawa 1991, s. 343-344.

${ }^{34}$ CAW WBH, III-15-1, Rozkaz bojowy nr 13 dowódcy 1 DP, k. 35.

${ }^{35}$ K. Dideńko, Wojska Inżynieryjno-saperskie LWP 1943-1945 (organizacja i dziatania bojowe), Warszawa 1978, s. 74.

${ }^{36}$ CAMO, fond 208, opis 2548, D. 74, Dokład o bojewoj diejatielnosti WWS protiwnika i swoich sriedstw PWO wojsk 33. A (Аоклад о боевой деятельности ВВС противника и своих среАств ПВО войск 33. А), k. 409.

${ }^{37}$ Jesienią 1943 r. linia styczności wojsk na środkowym odcinku frontu wschodniego przebiegała blisko granicy Białorusi i Rosji, a sieć drogowa na Białorusi była lepiej rozbudowana niż na Smoleńszczyźnie. BArch-MA, RH 26-337-33, KTB Nr. 5 der 337. ID, k. 9-14. 
W okresie poprzedzającym bitwę pod Lenino warunki atmosferyczne działały na korzyść 1 DP. Pomimo trudów, jakich doświadczyli maszerujący żołnierze dywizji, udało się uniknąć start spowodowanych działaniem nieprzyjacielskiego lotnictwa. Niekorzystne warunki atmosferyczne miały na to znaczący wpływ, zaś 1 DP skoncentrowała się do bitwy pod Lenino w pełnym składzie.

\section{Wpływ warunków atmosferycznych na działania 1 DP w bitwie pod Lenino (12-13 października 1943)}

12 października 1943 r. temperatura powietrza według danych Frontu Zachodniego wynosiła: $\mathrm{w}$ nocy i godzinach porannych od $-4^{\circ} \mathrm{C}$ do $0^{\circ} \mathrm{C}$, w dzień zaś od $8^{\circ} \mathrm{C}$ do $11^{\circ} \mathrm{C}^{38}$. Według meldunków 33 Armii było to od -1 do $10^{\circ} \mathrm{C}^{39}$. Innych informacji dostarcza KTB niemieckiej $95 \mathrm{DP}$, według którego pierwszego dnia bitwy temperatura wahała się od $-1^{\circ} \mathrm{C}$ do $5^{\circ} \mathrm{C}^{40}$.

Według wszystkich źródeł narracyjnych poranek 12 października $1943 \mathrm{r}$. był mglisty, po ustąpieniu zaś mgły wyszło słońce, które świeciło na niemal bezchmurnym niebie do końca dnia. Potwierdzają to dane z meldunków Frontu Zachodniego, 33 Armii i 1 ALot. Jednoczenie we wszystkich tych źródłach pojawia się informacja, że mgły miały charakter miejscowy. Ponadto w meldunku 1 ALot wspomniane jest, że zamglenie ustąpiło o godz. $10.00^{41}$. W dokumentach 33 Armii dzień 12 października został określony jako widny ${ }^{42}$, identycznie jak w KTB niemieckiej $337 \mathrm{DP}^{43}$. W meldunkach Frontu Zachodniego i 1 ALot mowa jest o częściowym zachmurzeniu na wysokości około 1000 m, jednak należy zaznaczyć, że dotyczyło to znacznie większego obszaru niż pole bitwy pod Lenino. Widoczność według danych Frontu Zachodniego wynosiła we mgle do 200-1000 m, a po jej ustąpieniu 6-10 km. Szczegółowych danych dostarcza na ten temat meldunek 1 ALot: w ciągu nocy i godzin porannych widoczność wahała się w przedziale od 5-10 km, natomiast w miejscach, gdzie wystąpiła mgła

\footnotetext{
38 CAMO, fond 208, opis 2511, D. 2545, Opierswodka N 480 Sztaba FZ, k. 65.

39 CAMO, fond 388, opis 8712, D. 429, Opierswodka N 482 Sztaba 33. Armii, k. 81.

40 BArch-MA, RH 26-95/38, Anlagenband 2 zum KTB Nr. 5 der 95. ID.

${ }^{41}$ CAMO, fond 290, opis 0003284, D. 0296, Opierswodka N² 283 Sztaba 1. WA, k. 152.

${ }^{42}$ CAMO, fond 388, opis 8712, D. 429, Opierswodka Nº 482 Sztaba 33. Armii, k. 81.

${ }_{43}$ BArch-MA, RH 26-337-33, KTB Nr. 5 der 337. ID, k. 15-16.
} 
do $150-300 \mathrm{~m}$; w ciągu dnia 4-10 km, a przy mgle do $1000 \mathrm{~m}$. Wiatr powiewał z kierunku północno-zachodniego z prędkością $0-3 \mathrm{~m} / \mathrm{s}^{44}$.

Kluczowe dla przebiegu pierwszego dnia bitwy pod Lenino było wystąpienie mgły w godzinach porannych. Warunki meteorologiczne tego dnia nie były niczym nietypowym dla połowy października, niemniej decyzje podjęte przez dowództwo Frontu Zachodniego i 33 Armii spowodowały, że czynnik pogodowy zadziałał na korzyść strony niemieckiej.

Z lektury wspomnień wynika, że mgła o świcie była bardzo gęsta i skutecznie blokowała wgląd w niemieckie pozycje na zachodnim brzegu rzeki Miereja. Za przykład służą relacje zastępcy ds. liniowych 2 kompanii fizylierów 2 pp, chor. Władysława Bąka oraz dowódcy 3 dywizjonu 1 pułku artylerii lekkiej, kpt. Leona Dubickiego: „Świta. Leżymy i choć mogła zasłania widoczność, obserwujemy przedpole. Ja i chorąży Arcimowicz znamy je dobrze z trzydniowej obserwacji, ale porucznik Siemianowicz i reszta wytęża wzrok. Nic nie widzę, nawet Miereji”`5 . „Nastrój napięcia i oczekiwania wzrastał w miarę zmniejszania się widoczności z powodu zamglenia, powstającego przy kondensacji pary wodnej na nizinach w postaci mgły, która zaciągnęła już dolinę Miereji, a po tym stopniowo cały widnokrąg i wzg. 215,5, które nikło już całkowicie za mgłą. Widoczność spadła do minimum"46.

W dzienniku działań bojowych 1 DP podana jest informacja, że mgła ograniczyła widzialność do $150-200 \mathrm{~m}^{47}$. Wystąpienie tak silnego zamglenia zbiegło się w czasie z tragicznym w skutkach rozpoznaniem bojem 1 batalionu 1 pp. Rozkaz do rozpoznania bojem wydał dowódca gen. Gordow w godzinach popołudniowych 11 października ${ }^{48}$.

W okresie II wojny światowej taka forma rozpoznania była powszechną praktyką stosowaną przez Armię Czerwoną. Zasadność posługiwania się tą taktyką po dziś dzień jest kwestią sporną. W wielu przypadkach rozpoznanie bojem przynosiło ograniczone korzyści, kosztem wysokich strat, w innych jednakże pozwalało w porę wykryć odw rót nieprzyjaciela i zaoszczędzić amunicję artyleryjską. Od umiejętności i wiedzy dowódcy zależało, kiedy skutecznie zastosować tę taktykę.

\footnotetext{
${ }^{44}$ CAMO, fond 290, opis 0003284, D. 0296, Opierswodka N² 283 Sztaba 1. WA, k. 152.

45 W. BĄK, Pieszo i konno, Warszawa 1963, s. 120.

${ }^{46}$ IX.4.44.286, L. Dubicki, Mój udział w bitwie pod Lenino, s. 56a.

${ }^{47}$ CAW WBH, III-7-15, Dziennik działań bojowych 1 Dywizji Piechoty im. T. Kościuszko, k. 8.

${ }^{48}$ Ibidem, $\mathrm{k} 6$.
} 
Przez pryzmat warunków, jakie wystąpiły o świcie 12 października 1943 r. można negować sens rozkazu gen. Gordowa, jednak w momencie jego wydawania (11 października) istniały pewne przesłanki, które wskazywały na możliwość powodzenia. Według danych 33 Armii z 11 października, mgła wystąpiła tylko w dolinie Miereji, ograniczając widoczność do $1000 \mathrm{~m}$. W meldunku 1 ALot pojawia się informacja o mgle radiacyjnej, czyli takiej, która występuje tylko przy gruncie ${ }^{49}$. W przypadku gdyby podobne warunki powtórzyły się 12 października zadziałałby to na korzyć żołnierzy 1 batalionu. Niska mgła mogła osłonić atakujących przed obserwacją wzrokową ze strony nieprzyjaciela podczas pokonywania doliny Miereji, jednocześnie nie zakrywając większości celów na wzniesieniach po zachodniej stronie rzeki. Jednak o świcie 12 października mgła była gęstsza i sięgała wyżej niż w dniu poprzednim. Mimo to rozkaz do rozpoznania bojem nie został odwołany. 1 batalion piechoty rozpoczął wykonywanie zadania o godzinie 6.00. Wpływ mgły na przebieg walki przedstawia relacja gen. Berlinga: „Wstała gęsta mgła. Unosiła się niskim falującym pułapem nad dnem doliny rzeki. Pod nim, przez błękitną zasłonę oparu, widziałem przed sobą tylko fragmentaryczne przedpole przedniego skaju obrony niemieckiej. [...] Widziałem przed sobą majaczące we mgle sylwetki prawego skrzydła nacierającego batalionu. [...] Część batalionu zaległa na tamtym brzegu i otwarła ogień, reszta poszła naprzód i zniknęła we mgle. Nic więcej nie widać... [Po pewnym czasie] Nasi się wycofują [...] podniósł się w górę ledwie widoczny we mgle, sygnał rakietą: żądamy ognia artylerii” ${ }^{50}$.

Wyniki rozpoznania bojem pozwoliły na stwierdzenie, że nieprzyjaciel wciąż broni się na zajmowanych pozycjach, co było wiadomo przed jego przeprowadzeniem. Z uwagi na gęstą mgłę, dowództwu artylerii 33 Armii, nie udało się uzyskać nowych danych na temat niemieckiego systemu ognia ${ }^{51}$.

Poprzedzające natarcie przygotowanie ogniowe artylerii 33 Armii miało rozpocząć się o godz. 8.20, jednak ze względu na wciąż zalegającą mgłę jego termin przesunięto na godz. 9.2052. Rozkaz w tej sprawie o godzinie 7.00 wydał dowódca Frontu Zachodniego, marsz. Wasilij Sokołowski. Decyzja ta może zaskakiwać z uwagi na fakt, że dowództwo artylerii 33 Armii dysponowało stosunkowo

\footnotetext{
49 CAMO, fond 290, opis 0003284, D. 0296, Opierswodka N²82 Sztaba 1. WA, k. 150.

50 Z. BERLING, op. cit., s. 393-394.

${ }^{51}$ CAW WBH, III-7-15, Dziennik działań bojowych 1 Dywizji Piechoty im. T. Kościuszko, k. 6.

${ }^{52}$ CAW WBH, III-7-3, s. 31-35.
} 
szczegółowymi informacjami na temat rozmieszczenia niemieckich środków ogniowych i umocnień polowych. W dokumentach sztabu 1 DP znajduje się mapa niemieckich pozycji wraz ze współrzędnymi celów, oparta na wynikach rozpoznania lotniczego ${ }^{53}$. Posiadanie takich danych umożliwiało prowadzenie ostrzału przy ograniczonej widoczności lub w nocy, problematyczne było jedynie korygowanie ognia i ocena jego skuteczności. Ponadto utrzymująca się mgła osłoniłaby natarcie piechoty przez Miereję przed wzrokiem niemieckich żołnierzy. Wątpliwości w tej kwestii wyraził kpt. Leon Dubicki: „Miałem odmienne zdanie co do mgły, która moim zdaniem wcale nie przeszkadzała w wykonaniu artyleryjskiego przygotowania ataku, ponieważ ognie planowe nie wymagają korygowania i obserwacji. [...] Mgła nawet sprzyjała naszemu natarciu, ponieważ odbywało się ono bez wsparcia lotniczego [dla strony niemieckiej], które wymaga dobrej widoczności. Dla piechoty mgła była tzw. „darem niebios”, ponieważ pod jej osłoną (niby za zasłoną dymną) mogła ona po zakończeniu artyleryjskiego przygotowania ataku zbliżyć się, bez większych strat do pierwszej transzei [...] Broń ciężka i artyleria nieprzyjaciela nie miałaby możliwości celnego ognia" ${ }^{4}$.

Pomimo przesunięcia o godzinę terminu przygotowania artyleryjskiego mgła nie opadła w momencie rozpoczęcia ostrzału. Gdy o godzinie 9.20 artyleria 33 Armii otwarła ogień widoczność wciąż nie była dostateczna, co uniemożliwiło skuteczną obserwację skutków ostrzału i tak jak godzinę wcześniej zmuszało artylerzystów do prowadzenia ognia tylko na podstawie wcześniej uzyskanych danych. Ponadto bombardowanie artyleryjskie niemieckich pozycji trwało tylko 40 minut, zamiast planowanych 100 minut $^{55}$.

Zgodnie z meldunkiem 1 ALot mgły zaczęły ustępować około godziny $10.00^{56}$. O tej samej godzinie gen. Berling otrzymał telefonicznie rozkaz gen. Gordowa, w którym poleca on natychmiast rozpocząć natarcie piechoty ${ }^{57}$. Między godziną 12.00 a 12.30 nad pole bitwy pod Lenino nadleciały samoloty bojowe niemieckiej 6 Floty Powietrznej. W pierwszej kolejności zbombardowano pozycje polskiej i sowieckiej artylerii, a następnie czołgi 1 pułku czołgów

53 CAW WBH, III-7-546, Schemat rozmieszczenia umocnień i punktów nieprzyjaciela wg rozpoznania lotniczego, k. 37; Współrzędne celów artylerii 1-szej PDP na bój 12 października 43 r., s. 39.

54 CAW WBH, IX.4.44.286, L. Dubicki, Mój udział w bitwie pod Lenino, s. 57-58.

55 CAW WBH, III-7-15, Dziennik działań bojowych 1 Dywizji Piechoty im. T. Kościuszko, k. 8.

56 CAMO, fond 290, opis 0003284, D. 0296, Opierswodka Nº 283 Sztaba 1. WA, k. 152.

57 CAW WBH, III-7-15, Dziennik działań bojowych 1 Dywizji Piechoty im. T. Kościuszko, k. 8. 
i szyki 1 i 2 pp. Bombardowania przybrały charakter ciągły i trwały aż do godzin wieczornych. Słoneczna pogoda i doskonała widoczność wydatnie sprzyjały niemieckiemu lotnictwu, umożliwiając dokonywanie precyzyjnych nalotów. Świadectwem bezradności żołnierzy wobec niemieckiej przewagi w powietrzu jest relacja chor. Romana Marchwickiego z 3 pp: „Właśnie przed chwilą Luftwaffe przystąpiła do gwałtownego i zmasowanego ataku na zajmowane przez nas pozycje. Zupełnie bezkarnie, nie napotykając na żaden przeciwlotniczy opór z naszej strony, samoloty z czarnymi krzyżami rozpoznawczymi krążyły nad rejonem, zrzucając na nas bomby. [...] Kiedy jedna partia samolotów odlatywała, następna nadchodziła i w podobny sposób, bez żadnych przeszkód kontynuowała rozpoczęte przez swoich poprzedników, niszczycielskie dzieło. Nawet bezchmurne tego dnia niebo - ku naszej rozpaczy - było sprzymierzeńcem wrażego lotnictwa"58.

W dokumencie o nazwie Opisanie operacyj po wsparciu natarcia 1-go p.p. 1-szym P.A.L. na odcinku m. Lenino za okres 1110 do 13.10 .43 r. podana jest informacja, że szyki 1 p [ułku] a[rtylerii] l[ekkiej] były bombardowane 12 razy w ciągu doby przez bombowce lecące w grupach 17-32 samolotów ${ }^{59}$.

13 października 1943 r. 1 DP ponowiła próbę przełamania niemieckich pozycji na zachód od Lenino. Pogoda w ciągu doby była podobna do tej z dnia poprzedniego. Temperatura powietrza drugiego dnia bitwy, według danych Frontu Zachodniego, wynosiła od $-5^{\circ} \mathrm{C}$ do $13^{\circ} \mathrm{C}^{60}$; na podstawie meldunku 33 Armii było to od $-3^{\circ} \mathrm{C}$ do $10^{\circ} \mathrm{C}^{61}$; a w KTB niemieckiej $95 \mathrm{DP}$ od $-4^{\circ} \mathrm{C}$ do $5^{\circ} \mathrm{C}^{62}$.

Podobnie jak w dniu poprzednim na obszarze działań Frontu Zachodniego wystąpiły liczne zamglenia i mgły, ograniczające widoczność do 500 m. Mgły utrzymywały się do godziny $10.00^{63}$. Niebo było bezchmurne. Wiatr północno-zachodni w rejonie działań 33 Armii poruszał masy powietrza z prędkością $0-2 \mathrm{~m} / \mathrm{s}^{64}$.

\footnotetext{
58 R. MARCHWICKI, op. cit., s. 197-198.

59 CAW, III-7-546, k. 62.

${ }^{60}$ CAMO, fond 208, opis 2511, D. 2545, Opierswodka N ${ }^{\circ} 481$ Sztaba FZ, k. 71

${ }^{61}$ CAMO, fond 388, opis 8712, D. 429, Opierswodka No 483 Sztaba 33. Armii, k. 83.

${ }^{62}$ BArch-MA, RH 26-95/38, Anlagenband 2 zum KTB Nr. 5 der 95. ID.

${ }^{63}$ CAMO, fond 208, opis 2511, D. 2545, Opierswodka N ${ }^{\circ} 481$ Sztaba FZ, k. 71

${ }^{64}$ CAMO, fond 388, opis 8712, D. 429, Opierswodka Nº 483 Sztaba 33. Armii, k. 83.
} 
Drugi dzień bitwy również rozpoczął się od przygotowania artyleryjskiego. Ostrzał wykonano między 7.30 a 8.00 pomimo wciąż silnego zamglenia. 13 października 1943 r. mgła była rzadsza, jednak jej wystąpienie stało się przyczyną niskiej skuteczności ognia. W odróżnieniu od dnia poprzedniego, na skutek natarcia 1 DP, lista celów dla artylerii zdezaktualizowała się, a współrzędne lokalizacji nowych stanowisk ogniowych wojsk niemieckich były podawane tylko na podstawie meldunków płynących z poddziałów 1 i 2 pp. Ich skuteczne porażanie wymagało czasu i dobrej widoczności niezbędnej przy wstrzeliwaniu ${ }^{65}$.

Natarcie 1 DP rozpoczęło się 13 października 1943 r. o godzinie 8.00, a więc jeszcze pod osłoną mgły. Podobnie jak w dniu poprzednim, około południa, nad pole bitwy nadleciało lotnictwo nieprzyjaciela. Bombardowania były jeszcze bardziej intensywne niż te z 12 października. Przeciętnie w ciągu dwóch dni bitwy niemieckie lotnictwo dokonywało nalotów w odstępach 15-20 minut po 15-45 samolotów ${ }^{66}$.

W ciągu dwóch pierwszych dni średnia temperatura powietrza według danych Armii Czerwonej wyniosła średnio $3,8-4^{\circ} \mathrm{C}$ na dobę ${ }^{67}$, według zaś KTB niemieckiej $95 \mathrm{DP}$ było to $1,25^{\circ} \mathrm{C}^{68}$. Zarówno pierwszego, jak i drugiego dnia bitwy, od świtu do godziny 10.00 widoczność w dolinie Miereji była ograniczona przez mgłę. Bezchmurne i niemal bezwietrzne niebo stwarzało korzystne warunki dla działań sił lotniczych.

W trakcie dwóch pierwszych dni trwania bitwy warunki pogodowe lepiej wykorzystała strona niemiecka, koncentrując do odparcia uderzenia $33 \mathrm{Ar}$ mii pokaźne siły lotnicze. W dniu 12 października 1943 r. jednostki obrony przeciwlotniczej (OPL) 33 Armii naliczyły 205 samolotolotów, a 13 października aż 455 samolotolotów. Dowództwo 33 Armii określiło niemieckie na-

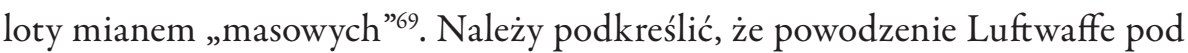

${ }^{65}$ CAW WBH, III-7-15, Dziennik działań bojowych 1 Dywizji Piechoty im. T. Kościuszko, k. 11.

${ }^{66}$ CAW WBH, III-7-546, Sprawozdanie z działalności bojowej artylerii 1 PDP im. T. Kościuszki przydzielonych i wspomagających oddziałów Armii Czerwonej za okres bojów 11-14.10.43, k. 86.

${ }^{67}$ CAMO, fond 208, opis 2511, D. 2545, Opierswodka N ${ }^{\circ}$ 480-481 Sztaba FZ, k. 65, 71; fond 388, opis 8712, D. 429, Opierswodka $N^{\circ}$ 482-483 Sztaba 33. Armii, k. 81, 83.

${ }_{68}$ BArch-MA, RH 26-95/38, Anlagenband 2 zum KTB Nr. 5 der 95. ID. BArch-MA, RH 2695/38, Anlagenband 2 zum KTB Nr. 5 der 95. ID.

${ }^{69}$ CAMO, fond 208, opis 2548, D. 74, Dokład o bojewoj diejatielnosti WWS protiwnika i swoich sriedstw PWO wojsk Zapf za pieriod s 1 oktiabria po 1 nojabria 1943 goda (АоклаА о боевой деятельности ВВС противника и своих среАств ПВО войск ЗапФ за период с 1 октября по 1 ноября 1943 года), k. 456. 
Lenino wynikało ze słabości sowieckiej OPL i niedostatecznego wsparcia ze strony 1 ALot, ponieważ pogoda był czynnikiem, który działał na korzyść obu stron.

\section{Pogoda w bitwie pod Lenino po wycofaniu 1 DP (14-17 października 1943)}

Straty $1 \mathrm{DP}$, oraz przypadki przechodzenia żołnierzy na stronę niemiecką, stały się przyczyną decyzji gen. Gordowa o wycofaniu dywizji z bitwy pod Lenino. Miejsce 1 DP zajęła sowiecka 164 DS, wchodząca dotychczas w skład drugiego rzutu armii ${ }^{70}$. Działania zaczepne pomiędzy Połzuchami a Trigubową były kontynuowane do 17 października $1943 \mathrm{r}$. W tym czasie $1 \mathrm{DP}$ znajdowała się w odwodzie 33 Armii w rejonie wsi Nikolajewka ${ }^{71}$.

W okresie 14-17 października 1943 r. pogoda stopniowo zmieniała się na niekorzyść sił lotniczych. Zachmurzenie zwiększało się. Średnia temperatura powietrza według danych Frontu Zachodniego wyniosła 5,8-6,4 $4^{\circ} \mathrm{C}^{72}$. Dzień 14 października 1943 r. przypominał ten poprzedni i był zarazem najchłodniejszym dniem tego okresu: $-1-13^{\circ} \mathrm{C}$ w ciągu dnia ${ }^{73}$. Rano wystąpiła mgła, ograniczająca widoczność do $1000 \mathrm{~m}$. Reszta dnia była pogodna. W toku kolejnych trzech dni występowały już tylko przygruntowe zamglenia, a widoczność pozostawała niezmienna, od 4 do $10 \mathrm{~km}$. W dniach 15-17 października zachmurzenie wzrosło od zmiennego do całkowitego. W pasie działania 33 Armii nie odnotowano opadów atmosferycznych, jednak informacja o deszczu pojawiała się w meldunku Frontu Zachodniego z 17 października ${ }^{74}$.

Dalszy ciąg bitwy pod Lenino, po wycofaniu 1 DP nie przyniósł siłom Frontu Zachodniego rozstrzygnięcia operacyjnego. Nawet na szczeblu taktycznym nie odnotowano sukcesów. Do końca trwania bitwy niemieckie lotnictwo

70 CAMO, fond 208, opis 2511, D. 2408, Opisanije bojewych diejstwij 1-j Polskoj piechotnoj diwizii za 12 i 13.10.43 (Описание боевых действий 1-й Польской пехотной дивизии за 12 и 13.10 .43$)$, k. 50.

71 CAW WBH, III-7-15, Dziennik działań bojowych 1 Dywizji Piechoty im. T. Kościuszko, k. 12.

72 CAMO, fond 208, opis 2511, D. 2545, Opierswodki sz. FZ, k. 71-94.

73 CAMO, fond 208, opis 2511, D. 2545, Opierswodka N 482 sz. FZ, k. 76.

74 CAMO, fond 208, opis 2511, D. 2545, Opierswodki sz. FZ, k. 71-94. 
dokonywało silnych nalotów na nacierające poddziały 33 Armii. Wyjątek stanowi 17 października. Przez cały dzień niebo było całkowicie zachmurzone, z pokrywą chmur na wysokości $600-1500 \mathrm{~m}$. O godz. 14.00 pododdziały z 42, 173, 164, 290 i 222 DS podjęły ostatnią próbę przełamania frontu, która szybko załamała się pod ogniem artylerii i broni maszynowej. Ostatniego dnia bitwy niemieckie lotnictwo nie interweniowało. O ile 16 października OPL 33 Armii zapisała 372 samolotoloty niemieckiego lotnictwa, to 17 października było ich już tylko $15^{75}$.

\section{Podsumowanie}

Stan pogody w połowie października 1943 r. nie był czynnikiem decydującym o przebiegu bitwy pod Lenino. Niepowodzenie 33 Armii w drugiej orszańskiej operacji zaczepnej wynikało z szeregu innych przyczyn, mimo że do listy błędów popełnianych przez sowieckie dowództwo można doliczyć nieelastyczne reagowanie na zmieniające się warunki atmosferyczne. Decyzja o przeprowadzeniu rozpoznania bojem w gęstej mgle, przesuniecie terminu rozpoczęcia przygotowania artyleryjskiego 12 października, a także wykonanie nawały ogniowej we mgle, bez aktualnych informacji o rozmieszczeniu punktów ogniowych nieprzyjaciela, świadczą o niedopasowaniu decyzji dowódczych do sytuacji na polu bitwy.

Poza występowaniem mgły, pogoda w czasie trwania bitwy pod Lenino nie wpłynęła w sposób istotny na działania wojsk lądowych. Dla lotnictwa korzystne warunki atmosferyczne stanowiły czynnik ułatwiający realizację stawianych zadań.

Według informacji zgromadzonych przez służbę obserwacyjno-meldunkową 33 Armii w ciągu całego października 1943 r. niemieckie lotnictwo wojskowe wykonało łącznie 2030 samolotolotów. W dniach od 12 do 16 października odnotowano średnio 388 samolotolotów na dobę ${ }^{76}$. Oznacza to, że z 2030

75 CAMO, fond 388, opis 8712, D. 456, Żurnał bojewych diejstwij 33. A. sientiabr'-nojabr' 1943 g. (Журнац боевых действий 33. А. сентябрь-ноябрь 1943 г.), k. 29.

${ }^{76}$ CAMO, fond 208, opis 2548, D. 74, Dokład o bojewojdiejatielnosti WWS protiwnika i swoichsriedstw PWO wojsk Zapf za pieriod s 1 oktiabria po 1 nojabria 1943 goda, k. 471. 
samolotolotów zarejestrowanych przez 33 Armię w dniach od 1 do 31 października, aż $83 \%$ przypada na czas trwania bitwy pod Lenino ${ }^{77}$. Wzrost aktywności niemieckiego lotnictwa nad szykami 33 Armii i sąsiadującej z nią 21 i 49 Armii ukazuje wykres 1.

\section{Wykres 1}

Liczba samolotolotów niemieckiego lotnictwa w rejonie Lenino według danych służby obserwacyjno-meldunkowej Frontu Zachodniego w październiku 1943 r.

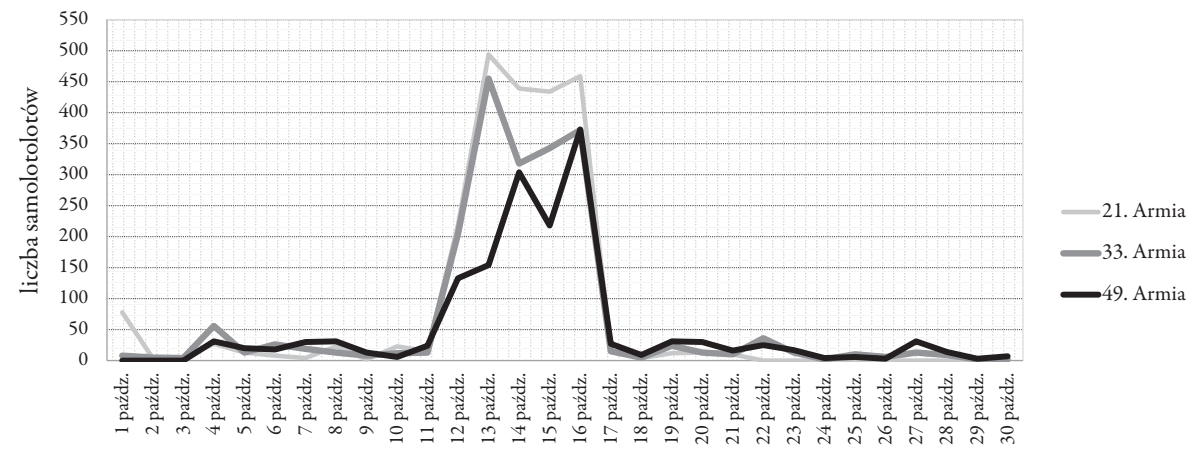

Źródło: CAMO, Fond 208, Opis 2548, D. 74, Dokład o bojewoj diejatielnosti WWS protiwnika i swoich sriedstw PWO wojsk Zapf za pieriod s 1 oktiabria po 1 nojabria 1943 goda, k. 471.

Uśredniony poziom zachmurzenia w skali dekanowej, w ciągu dnia w okresie od 1 do 17 października 1943 r., według danych sowieckiej 1 ALot, przedstawia wykres 2. Przejaśnienia przypadają na dni 6-9 października oraz 12-15 października. W odniesieniu do liczby samolotolotów niemieckiego lotnictwa widać, że okres wzmożenia lotów nie był powiązany jedynie ze sprzyjającą pogodą. W dniach 6-9 października aktywność Luftwaffe była minimalna, pomimo stosunkowo korzystnych warunków do działań lotnictwa.

Ponadprzeciętna koncentracja Luftwaffe nad rejonem działań bojowych 33 Armii i jej sąsiadów w dniach 12-16 października 1943 r., nie była spowodowana tylko i wyłącznie polepszeniem się warunków atmosferycznych.

77 CAMO, fond 208, opis 2548, D. 74, Dokład o bojewojdiejatielnosti WWS protiwnika i swoichsriedstw PWO wojsk Zapf za pieriod s 1 oktiabria po 1 nojabria 1943 goda, k. 471. 
Wykres 2

Poziom zachmurzenia według meldunków 1 Alot

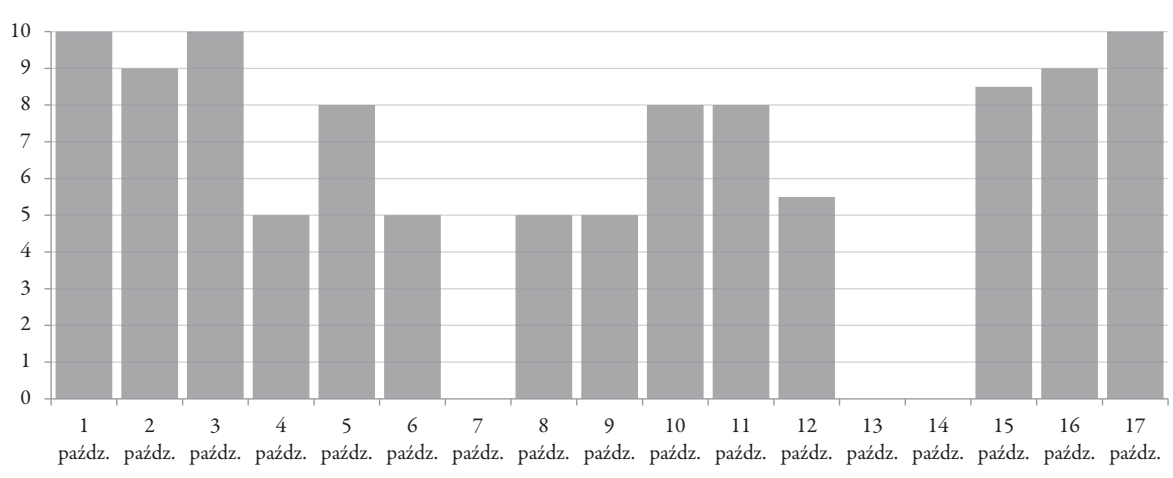

Źródło: CAMO, Fond 208, Opis 2511, D. 2545, Opierswodki N²72-288 Sztaba 1. WA, k. 140-160.

W dniu 11 października 1943 r. na stronę niemiecką zdezerterowało trzech polskich żołnierzy z 1 pp. Przekazali oni stronie niemieckiej informacje, że następnego dnia 33 Armia przystąpi do działań zaczepnych z kierunku Lenino $^{78}$. Żołnierze ci zdradzili również, że sztab gen. Gordowa znajduje się we wsi Pankow, w efekcie czego stanowisko to stało się celem nalotu, wkrótce po rozpoczęciu bitwy ${ }^{79}$. Strona niemiecka pozyskawszy informację o dacie i miejscu planowanej ofensywy Frontu Zachodniego, sięgnęła po atut w postaci jednostek lotniczych ze składu 6 Floty Powietrznej. Dokonały one koncentracji swych sił na kluczowym odcinku. Jednoczenie dowództwo Frontu Zachodniego i 1 ALot nie było przygotowane na taki obrót wypadków i utraciło inicjatywę w powietrzu na rzecz Luftwaffe. W ramach podsumowania można stwierdzić, że strona niemiecka dzięki uzyskanej przewadze wywiadowczej zdołała lepiej wykorzystać warunki pogodowe na swoją korzyść. Zaangażowanie dużych sił lotniczych, przy sprzyjającej pogodzie, dało pożądany skutek, za co krwawą cenę zapłacili żołnierze $1 \mathrm{DP}$.

${ }_{78}$ BArch-MA, RH26-337/33. Kriegstagebuch Nr. 5 der 337. Inf. Div, k. 14.

79 Pankowo było jedną z miejscowości, przez którą przemieszczała się $1 \mathrm{DP}$, toteż miejsce rozlokowania sztabu 33. Armii nie było dla żołnierzy tajemnicą. CAMO, fond 208, opis 2511, D. 2408, Opisanije bojewych diejstwij 1-j Polskoj piechotnoj diwizii za 12 i 13.10, k. 48; O bojewych diejstwijach 1 -j Polskoj piechotnoj diwizii, k. 60. 


\section{Załącznik}

\section{Warunki atmosferyczne w okresie 1-17 października 1943 r. według meldunków Frontu Zachodniego, 1 ALot i 33 Armii}

\begin{tabular}{|c|c|}
\hline \multicolumn{2}{|r|}{1 października 1943 r. } \\
\hline Front Zachodni: & $\begin{array}{l}\text { Zachmurzenie całkowite na wysokości } 100-400 \mathrm{~m} \text {, w ciągu dnia przeja- } \\
\text { śnienia i podwyższenie podstawy chmur do wysokości } 700 \mathrm{~m} \text {. Przelotne } \\
\text { deszcze i mżawki. Widoczność w nocy } 0,5-3 \mathrm{~km} \text {, w ciągu dnia } 6-10 \mathrm{~km} \text {. } \\
\text { Wiatr nocą południowy, } 1-5 \mathrm{~m} / \mathrm{s} \text {, w ciągu dnia zachodni } 4-9 \mathrm{~m} / \mathrm{s} \text {. Tem- } \\
\text { peratura } 7-11 \text { stopni. Drogi dla transportu samochodowego trudno } \\
\text { przejezdne. }\end{array}$ \\
\hline 1 Armia Lotnicza: & $\begin{array}{l}\text { Zachmurzenie nocą } 10 / 10 \text { punktów, na wysokości } 100-400 \mathrm{~m} \text { wieczo- } \\
\text { rem, ranem zaś } 100-500 \mathrm{~m} \text {. Mżawka z mgłą. Widoczność do } 2-3 \mathrm{~km} \text {, } \\
\text { a w miejscach, gdzie wystąpiła mgła do } 200 \mathrm{~m} \text {. W ciągu dnia zachmurze- } \\
\text { nie } 10 / 10 \text { punktów na wysokości } 100-200 \mathrm{~m} \text {. Mżawka z mgłą. W dru- } \\
\text { giej połowie dnia zachmurzenie } 5-7 / 10 \text { punktów, na wysokości do } 500- \\
700 \mathrm{~m} \text {, widoczność do } 6-10 \mathrm{~km} \text {, a przy mgle } 200-500 \mathrm{~m} \text {. }\end{array}$ \\
\hline 33 Armia: & $\begin{array}{l}\text { Pochmurno, pod koniec okresu przejaśnienia. Wiatr południowo- } \\
\text {-wschodni } 0-3 \mathrm{~m} / \mathrm{s} \text {. Temperatura powietrza od } 5^{\circ} \mathrm{C} \text { do } 10^{\circ} \mathrm{C} \text {. }\end{array}$ \\
\hline \multicolumn{2}{|r|}{2 października 1943 r. } \\
\hline Front Zachodni: & $\begin{array}{l}\text { Zachmurzenie całkowite na wysokości } 100-800 \mathrm{~m} \text {. Przelotne deszcze, } \\
\text { mżawki i zamglenia. Widoczność } 4-6 \mathrm{~km} \text {, przy mżawce i zamgleniu } \\
1-2 \mathrm{~km} \text {. Wiatr zachodni } 2-5 \mathrm{~m} / \mathrm{s} \text {. Temperatura } 10-13^{\circ} \mathrm{C} \text { w ciągu dnia. } \\
\text { Głębokie koleiny i wyboje wszędzie utrudniają przejezdność dróg grun- } \\
\text { towych. Na drogach położonych w obniżeniach terenu oraz na drogach } \\
\text { leśnych występują trudności dla ruchu samochodów. }\end{array}$ \\
\hline 1 Armia Lotnicza: & $\begin{array}{l}\text { Nocą zachmurzenie } 8-10 / 10 \text { punktów, na wysokości } 400-800 \mathrm{~m} \text { w ciągu } \\
\text { nocy. Miejscami deszcze. Widoczność } 4-10 \mathrm{~km} \text {, przy deszczu zaś } 1-2 \mathrm{~km} \text {. } \\
\text { Widoczność do } 2-3 \mathrm{~km} \text {. W ciągu dnia zachmurzenie } 10 / 10 \text { punktów, na } \\
\text { wysokości } 200-600 \mathrm{metrów} \text {, miejscami na } 100 \mathrm{~m} \text {. Zamglenie i mżawka. } \\
\text { Widoczność na } 2-4 \mathrm{~km} \text {, a przy opadach } 1-2 \mathrm{~km} \text {. }\end{array}$ \\
\hline 33 Armia: & $\begin{array}{l}\text { Mgty i zamglenia. Wiatr zachodni } 1-3 \mathrm{~m} / \mathrm{s} \text {. Temperatura powietrza } \\
\text { w przedziale od } 8^{\circ} \mathrm{C} \text { do } 13^{\circ} \mathrm{C} \text {. }\end{array}$ \\
\hline \multicolumn{2}{|r|}{3 października 1943 r. } \\
\hline Front Zachodni: & $\begin{array}{l}\text { Zachmurzenie całkowite na wysokości } 100-500 \mathrm{~m} \text {. Deszcz, zamglenia } \\
\text { i mgły. Widoczność } 2-4 \mathrm{~m} \text {, przy mgle i zamgleniu mniej niż } 1 \mathrm{~km} \text {. Wiatr } \\
\text { zachodni } 4-8 \mathrm{~m} / \mathrm{s} \text { z porywami do } 10-15 \mathrm{~m} / \mathrm{s} \text {, na wysokości } 500 \mathrm{~m} \text { do } \\
20 \mathrm{~m} / \mathrm{s} \text {. Temperatura } 8-14^{\circ} \mathrm{C} \text {. Drogi dla transportu samochodowego } \\
\text { trudno przejezdne. }\end{array}$ \\
\hline
\end{tabular}




\begin{tabular}{|c|c|}
\hline 1 Armia Lotnicza: & $\begin{array}{l}\text { Nocą zachmurzenie } 10 / 10 \text { punktów, na wysokości } 200-500 \mathrm{~m} \text {. Mgły i za- } \\
\text { mglenia. Widoczność do } 2-4 \mathrm{~km} \text {, a w miejscach, gdzie wystąpiła mgła } \\
\text { do } 1000 \mathrm{~m} \text {. W ciągu dnia zachmurzenie } 10 / 10 \text { punktów, na wysokości } \\
100-300 \mathrm{~m} \text {. Przelotne deszcze z chmur na wysokości } 50-100 \text { metrów. } \\
\text { Widoczność } 1-4 \mathrm{~km} \text {, okresowo może spadać poniżej } 1 \mathrm{~km} \text {. }\end{array}$ \\
\hline 33 Armia: & $\begin{array}{l}\text { Zachmurzenie zmienne. Rano i wieczorem deszcz. Mgły i zamglenia. } \\
\text { Wiatr poludniowo-zachodni, porywisty } 1-5 \mathrm{~m} / \mathrm{s} \text {. Temperatura powie- } \\
\text { trza w przedziale od } 7^{\circ} \mathrm{C} \text { do } 13^{\circ} \mathrm{C} \text {. }\end{array}$ \\
\hline \multicolumn{2}{|r|}{4 października 1943 r. } \\
\hline Front Zachodni: & $\begin{array}{l}\text { Przeważnie pogodnie. Rano chmury na wysokości } 100-200 \mathrm{~m} \text {. Deszcz, } \\
\text { zamglenia i mgły, przelotne deszcze. Widoczność } 4-10 \mathrm{~m} \text {. Wiatr zachod- } \\
\text { ni } 5-12 \mathrm{~m} / \mathrm{s} \text { z porywami do } 15-17 \mathrm{~m} / \mathrm{s} \text {. Temperatura } 4-14^{\circ} \mathrm{C} \text {. Drogi } \\
\text { dla transportu samochodowego trudno przejezdne. }\end{array}$ \\
\hline 1 Armia Lotnicza: & $\begin{array}{l}\text { Nocą zachmurzenie } 5-10 / 10 \text { punktów, na wysokości } 100-300 \mathrm{~m} \text {. } \\
\text { Deszcz w pierwszej połowie nocy. Przejaśnienia w ciągu reszty nocy do } \\
\text { rana. Widoczność do } 4-10 \mathrm{~km} \text {, w czasie deszczu zaś } 500-2000 \mathrm{~m} \text {. Wiatr } \\
15-17 \mathrm{~m} / \mathrm{s} \text {. W ciągu dnia zachmurzenie } 3-7 / 10 \text { punktów, na wysokości } \\
300-600 \mathrm{~m} \text {, a w godzinach porannych } 100-200 \mathrm{~m} \text {. Zamglenia. Widocz- } \\
\text { ność } 4-10 \mathrm{~km} \text {. }\end{array}$ \\
\hline 33 Armia: & $\begin{array}{l}\text { Przeważnie jasno. Wiatr południowo-zachodni, porywisty } 1-5 \mathrm{~m} / \mathrm{s} \text {. } \\
\text { Temperatura powietrza w przedziale od } 3^{\circ} \mathrm{C} \text { do } 13^{\circ} \mathrm{C} \text {. }\end{array}$ \\
\hline \multicolumn{2}{|r|}{5 października 1943 r. } \\
\hline Front Zachodni: & $\begin{array}{l}\text { Zachmurzenie zmienne na wysokości } 600-800 \mathrm{~m} \text {. Przelotny deszcz. Za- } \\
\text { mglenia. Widoczność } 4-10 \mathrm{~m} \text {, przy deszczu i zamgleniu } 1-2 \mathrm{~km} \text {. Wiatr } \\
\text { zachodni porywisty } 7-12 \mathrm{~m} / \mathrm{s} \text {. Temperatura } 4-17^{\circ} \mathrm{C} \text {. Na drogach poło- } \\
\text { żonych w obniżeniach terenu oraz na drogach leśnych występują trudności } \\
\text { dla ruchu samochodów. }\end{array}$ \\
\hline 1 Armia Lotnicza: & $\begin{array}{l}\text { Noc jasna, ranem zamglenia. Widoczność do } 4-10 \mathrm{~km} \text {. W ciągu dnia } \\
\text { zachmurzenie } 6-10 / 10 \text { punktów na wysokości } 600-800 \mathrm{~m} \text {. Rano za- } \\
\text { mglenia. W rejonie działań bojowych lekkie opady deszczu. Widoczność } \\
4-10 \mathrm{~km} \text {, przy deszczu zaś } 1-2 \mathrm{~km} \text {. }\end{array}$ \\
\hline 33 Armia: & $\begin{array}{l}\text { Noc widna, zamglenia. W dzień zachmurzenie zmienne, w nocy słaby } \\
\text { deszcz. Wiatr południowo-zachodni, porywisty } 3-7 \mathrm{~m} / \mathrm{s} \text {. Temperatura } \\
\text { powietrza w przedziale od } 6^{\circ} \mathrm{C} \text { do } 15^{\circ} \mathrm{C} \text {. }\end{array}$ \\
\hline \multicolumn{2}{|r|}{6 października 1943 r. } \\
\hline Front Zachodni: & $\begin{array}{l}\text { W nocy miejscami deszcz. Zachmurzenie zmienne, na wysokości } 300- \\
600 \mathrm{~m} \text {. Widoczność } 4-10 \mathrm{~km} \text {, w deszczu } 1-2 \mathrm{~km} \text {. Wiatr zachodni, } \\
\text { w nocy } 8-10 \mathrm{~m} / \mathrm{s} \text { z porywami do } 12-15 \mathrm{~m} / \mathrm{s} \text {, w ciągu dnia } 3-5 \mathrm{~m} / \mathrm{s} \text {. }\end{array}$ \\
\hline
\end{tabular}




\begin{tabular}{|c|c|}
\hline & $\begin{array}{l}\text { Temperatura powietrza } 7-13^{\circ} \mathrm{C} \text {. Drogi dla transportu samochodowego } \\
\text { trudno przejezdne. }\end{array}$ \\
\hline 1 Armia Lotnicza: & $\begin{array}{l}\text { Nocą zachmurzenie } 5-10 / 10 \text { punktów, na wysokości } 300-600 \mathrm{~m} \text {. } \\
\text { W pierwszej połowie nocy zamglenia na wysokości } 100-200 \mathrm{~m} \text {. Wi- } \\
\text { doczność } 4-10 \mathrm{~km} \text {, w przypadku zaś zamgleń } 1-2 \mathrm{~km} \text {. W ciągu dnia } \\
\text { zachmurzenie } 3-7 / 10 \text { punktów, chmury na wysokości } 300-600 \mathrm{~m} \text { oraz } \\
600-1500 \mathrm{~m} \text {. Widoczność } 6-10 \mathrm{~km} \text {. }\end{array}$ \\
\hline 33 Armia: & $\begin{array}{l}\text { Widno. Wiatr poludniowo-zachodni } 0-5 \mathrm{~m} / \mathrm{s} \text {. Temperatura powietrza } \\
\text { w przedziale od } 1^{\circ} \mathrm{C} \text { do } 13^{\circ} \mathrm{C} \text {. }\end{array}$ \\
\hline \multicolumn{2}{|r|}{7 października 1943 r. } \\
\hline Front Zachodni: & $\begin{array}{l}\text { Widno. Widoczność do } 15 \mathrm{~km} \text {. Wiatr południowo-zachodni } 2-8 \mathrm{~m} / \mathrm{s} \text {. } \\
\text { Temperatura w nocy od } 2 \text { do }-2^{\circ} \mathrm{C} \text {. W dzień } 14-16^{\circ} \mathrm{C} \text {. Na drogach grun- } \\
\text { towych błoto, koleiny i wyboje, powodujące trudności dla ruchu samo- } \\
\text { chodów ciężarowych. }\end{array}$ \\
\hline 1 Armia Lotnicza: & $\begin{array}{l}\text { Noc jasna. Zamglenia. Widoczność } 6-10 \mathrm{~km} \text {. Dzień bezchmurny. Wi- } \\
\text { doczność do } 10-15 \mathrm{~km} \text {. }\end{array}$ \\
\hline 33 Armia: & $\begin{array}{l}\text { Widno. Wiatr poludniowo-zachodni } 0-5 \mathrm{~m} / \mathrm{s} \text {, słaby do ciszy. Tempera- } \\
\text { tura powietrza w przedziale od } 5^{\circ} \mathrm{C} \text { do } 15^{\circ} \mathrm{C} \text {. }\end{array}$ \\
\hline \multicolumn{2}{|r|}{8 października 1943 r. } \\
\hline Front Zachodni: & $\begin{array}{l}\text { Noc jasna. W ciągu dnia zamglenia. Znaczne zachmurzenie, na wysoko- } \\
\text { ści } 600-1000 \mathrm{~m} \text {. Widoczność } 2-10 \mathrm{~km} \text {. Wiatr południowo-zachodni } \\
5-10 \mathrm{~m} / \mathrm{s} \text {. Temperatura powietrza } 5-8^{\circ} \mathrm{C} \text { w nocy i } 14-18^{\circ} \mathrm{C} \text { w dzień. Na } \\
\text { drogach gruntowych błoto, koleiny i wyboje, powodujące trudności dla } \\
\text { ruchu samochodów ciężarowych. }\end{array}$ \\
\hline 1 Armia Lotnicza: & $\begin{array}{l}\text { W ciągu nocy zachmurzenie od } 10 / 10 \text { punktów, zmniejszające się do } \\
0 / 10 \text { punktów. Chmury na wysokości } 200-500 \text {. Miejscami zamglenia. } \\
\text { W drugiej części nocy wystąpily mgły. Widoczność do } 4-10 \mathrm{~km} \text {, a w miej- } \\
\text { scach, gdzie wystąpiła mgła do } 500-2000 \text {. W ciągu dnia zachmurzenie } \\
\text { zwiększające się od bezchmurnego nieba rano do } 10 / 10 \text { punktów, wyso- } \\
\text { kość chmur } 300-600 \mathrm{~m} \text {. Widoczność } 4-10 \mathrm{~km} \text {. }\end{array}$ \\
\hline 33 Armia: & $\begin{array}{l}\text { Zachmurzenie zmienne. Rano i wieczorem deszcz. Wiatr południowo- } \\
\text {-zachodni } 0-3 \mathrm{~m} / \mathrm{s} \text {. Temperatura powietrza w przedziale od } 5^{\circ} \mathrm{C} \text { do } 18^{\circ} \mathrm{C} \text {. }\end{array}$ \\
\hline \multicolumn{2}{|r|}{9 października 1943 r. } \\
\hline Front Zachodni: & $\begin{array}{l}\text { Zachmurzenie malejące, na wysokości } 300-600 \mathrm{~m} \text {. Widoczność } 2-10 \mathrm{~km} \text {. } \\
\text { Rano mgła. Widoczność } 4-10 \mathrm{~km} \text {, a przy mgle do } 200 \mathrm{~m} \text {. Wiatr pół- } \\
\text { nocno-wschodni } 5-10 \mathrm{~m} / \mathrm{s} \text {. Temperatura powietrza } 2-10^{\circ} \mathrm{C} \text {. Na drogach } \\
\text { położonych w obniżeniach terenu oraz na drogach leśnych występują } \\
\text { trudności dla ruchu samochodów. }\end{array}$ \\
\hline
\end{tabular}




\begin{tabular}{|c|c|}
\hline 1 Armia Lotnicza: & $\begin{array}{l}\text { W pierwszych godzinach po zmroku zachmurzenie } 10 / 10 \text { punktów, } \\
\text { chmury na wysokości } 200-500 \text {. Miejscami zamglenia. W drugiej części } \\
\text { nocy wystąiły mgły. Widoczność do } 4-10 \mathrm{~km} \text {, a w miejscach, gdzie wy- } \\
\text { stąpiła mgła do } 200-500 \mathrm{~m} \text {. W ciągu dnia od bezchmurnego nieba rano } \\
\text { do } 10 / 10 \text { punktów, wysokość chmur } 300-600 \mathrm{~m} \text {. Widoczność na odle- } \\
\text { głość } 4-10 \mathrm{~km} \text {. }\end{array}$ \\
\hline 33 Armia: & $\begin{array}{l}\text { W nocy i rano widno, następnie wzrost zachmurzenia do całkowitego. } \\
\text { Bez opadów. Wiatr północny } 1-5 \mathrm{~m} / \mathrm{s} \text {. Temperatura powietrza w prze- } \\
\text { dziale } 1-9^{\circ} \mathrm{C} \text {. }\end{array}$ \\
\hline \multicolumn{2}{|r|}{10 października 1943 r. } \\
\hline Front Zachodni: & $\begin{array}{l}\text { Zachmurzenie częściowe. Widoczność } 4-10 \mathrm{~km} \text {. Wiatr południo- } \\
\text { wy } 1-4 \mathrm{~m} / \mathrm{s} \text {. Temperatura powietrza w nocy od }-1 \text { do }-3^{\circ} \mathrm{C} \text {, a w dzień } \\
7-10^{\circ} \mathrm{C} \text {. Na drogach położonych w lasach występują miejscowe trudności } \\
\text { dla ruchu samochodów. }\end{array}$ \\
\hline 1 Armia Lotnicza: & $\begin{array}{l}\text { W noc zachmurzenie 5-9/10 punktów, na wysokości } 600-1000 \mathrm{~m} \text { z prze- } \\
\text { jaśnieniami. W nocy zamglenia, a rano miejscami mgła. Widoczność do } \\
4-10 \mathrm{~km} \text {, a w miejscach, gdzie wystąpiła mgła do } 1000 \mathrm{~m} \text {. W ciągu dnia } \\
\text { zachmurzenie } 6-10 / 10 \text { punktów, wysokość } 600-1500 \mathrm{~m} \text {. Widoczność na } \\
\text { odległość } 6-10 \mathrm{~km} \text {. }\end{array}$ \\
\hline 33 Armia: & $\begin{array}{l}\text { Noc jasna. W dzień nieduże zachmurzenie, bez deszczu. Bezwietrznie } \\
\text { lub słaby wiatr północny. Temperatura powietrza w przedziale od }-2^{\circ} \mathrm{C} \\
\text { do } 9^{\circ} \mathrm{C} \text {. }\end{array}$ \\
\hline \multicolumn{2}{|r|}{11 października 1943 r. } \\
\hline Front Zachodni: & $\begin{array}{l}\text { Zachmurzenie częściowe. Rano mgła. W ciągu dnia mżawka lub deszcz. } \\
\text { Widoczność } 4-10 \mathrm{~km} \text {, przy mgle do } 1 \mathrm{~km} \text {. Wiatr zachodni } 0-5 \mathrm{~m} / \mathrm{s} \text {. } \\
\text { Temperatura powietrza w nocy od }-2 \text { do }-5^{\circ} \mathrm{C} \text {, a w dzień } 5-8^{\circ} \mathrm{C} \text {. Na } \\
\text { drogach położonych w lasach występują miejscowe trudności dla ruchu } \\
\text { samochodów. }\end{array}$ \\
\hline 1 Armia Lotnicza: & $\begin{array}{l}\text { W noc niebo zachmurzenie 5-9/10 punktów, na wysokości } 600-1000 \mathrm{~m} \text {. } \\
\text { Do rana rozpogodzenia. Zamglenia do } 9 \text { rano. Miejscami mgła radiacyj- } \\
\text { na. W ciągu dnia zachmurzenie } 6-10 / 10 \text { punktów, na wysokości } 600- \\
1500 \mathrm{~m} \text {. Widoczność na odległość } 6-10 \mathrm{~km} \text {. }\end{array}$ \\
\hline 33 Armia: & $\begin{array}{l}\text { Noc jasna, mgły tylko w dolinach. W ciagu dnia głównie pochmurno, bez } \\
\text { opadów. Bezwietrznie lub słaby wiatr północny. Temperatura powietrza } \\
\text { w przedziale od }-2 \text { do } 8^{\circ} \mathrm{C} \text {. }\end{array}$ \\
\hline \multicolumn{2}{|r|}{12 października 1943 r. } \\
\hline Front Zachodni: & $\begin{array}{l}\text { W nocy przejaśnienia. Chmury na wysokości } 600-1500 \mathrm{~m} \text {. Zamglenia, } \\
\text { miejscami mgła. Widoczność } 6-10 \mathrm{~km} \text {, przy mgle do } 200-1000 \mathrm{~km} \text {. } \\
\text { Wiatr południowy słaby. Temperatura powietrza w nocy od } 0 \text { do } 4^{\circ} \mathrm{C} \text {, }\end{array}$ \\
\hline
\end{tabular}




\begin{tabular}{|c|c|}
\hline & $\begin{array}{l}\text { a w dzień } 8-11^{\circ} \mathrm{C} \text {. Przejezdność dróg dostateczna, na obniżeniach tere- } \\
\text { nu utrudniona. }\end{array}$ \\
\hline 1 Armia Lotnicza: & $\begin{array}{l}\text { Noc jasna. Zamglenia i mgły. Widoczność do } 5-10 \mathrm{~km} \text {, a w miejscach, } \\
\text { gdzie wystąpiła mgła do } 150-300 \mathrm{~m} \text {. W ciągu dnia zachmurzenie 3-8/10 } \\
\text { punktów, na wysokości } 1000 \mathrm{~m} \text {. Mgły i zamglenia do godziny } 10 \text { rano. } \\
\text { Widoczność do } 4-10 \mathrm{~km} \text {, a w miejscach, gdzie wystąpiła mgła do } 1000 \mathrm{~m} \text {. }\end{array}$ \\
\hline 33 Armia: & $\begin{array}{l}\text { Jasno, rano mgła. Wiatr północno-zachodni } 0-3 \mathrm{~m} / \mathrm{s} \text {. Temperatura po- } \\
\text { wietrza w przedziale od }-1 \text { do } 10^{\circ} \mathrm{C} \text {. }\end{array}$ \\
\hline \multicolumn{2}{|r|}{13 października 1943 r. } \\
\hline Front Zachodni: & $\begin{array}{l}\text { Widno. Zamglenia. Rano miejscami mgła. Widoczność } 4-10 \mathrm{~km} \text {, przy } \\
\text { mgle do } 500 \mathrm{~m} \text {. Bezwietrznie. Temperatura powietrza od }-5^{\circ} \mathrm{C} \text { rano do } \\
13^{\circ} \mathrm{C} \text { w ciągu dnia. Na drogach położonych w lasach występują miejscowe } \\
\text { trudności dla ruchu samochodów. }\end{array}$ \\
\hline 1 Armia Lotnicza: & $\begin{array}{l}\text { Noc jasna. Zamglenia, a w drugiej połowie nocy mgły. Widoczność do } \\
4-10 \mathrm{~km} \text {, w miejscach zaś, gdzie wystąpiła mgła do } 1000 \mathrm{~m} \text {. W ciągu dnia } \\
\text { widno. Zamglenia do godziny } 10 \text { rano, miejscami mgła. Widoczność do } \\
4-10 \mathrm{~km} \text {, natomiast w miejscach, gdzie wystąpiła mgła do } 1000 \mathrm{~m} \text {. }\end{array}$ \\
\hline 33 Armia: & $\begin{array}{l}\text { Jasno. Wiatr północno-zachodni } 0-2 \mathrm{~m} / \mathrm{s} \text {. Temperatura powietrza w prze- } \\
\text { dziale od }-3^{\circ} \mathrm{C} \text { do } 10^{\circ} \mathrm{C} \text {. }\end{array}$ \\
\hline \multicolumn{2}{|r|}{14 października $1943 \mathrm{r}$. } \\
\hline Front Zachodni: & $\begin{array}{l}\text { W ciągu dnia jasno przy słabym wietrze. Widoczność } 4-10 \mathrm{~km} \text {, przy } \\
\text { mgle do } 1 \mathrm{~km} \text {. Bezwietrznie. Temperatura powietrza od }-1^{\circ} \mathrm{C} \text { rano do } 3^{\circ} \mathrm{C} \\
\text { w nocy, a wciągu dnia } 10-13^{\circ} \mathrm{C} \text {. Na drogach położonych w lasach wystę- } \\
\text { pują miejscowe trudności dla ruchu samochodów. }\end{array}$ \\
\hline 1 Armia Lotnicza: & $\begin{array}{l}\text { Noc jasna. Zamglenia, miejscami mgła. Widoczność do } 4-8 \mathrm{~km} \text {, a w miej- } \\
\text { scach, gdzie wystąpiły zamglenia i mgła do } 0,5-2 \mathrm{~km} \text {. W ciągu dnia jasno. } \\
\text { Do godziny } 10 \text { rano mgła ograniczająca widoczność do } 1 \mathrm{~km} \text { lub mniej. } \\
\text { Przy braku mgły widoczność do } 4-10 \mathrm{~km} \text {. }\end{array}$ \\
\hline 33 Armia: & $\begin{array}{l}\text { Jasno. Wiatr południowo-wschodni } 0-3 \mathrm{~m} / \mathrm{s} \text {. Temperatura powietrza } \\
\text { w przedziale od }-3^{\circ} \mathrm{C} \text { do } 12^{\circ} \mathrm{C} \text {. }\end{array}$ \\
\hline \multicolumn{2}{|r|}{15 października $1943 \mathrm{r}$. } \\
\hline Front Zachodni: & $\begin{array}{l}\text { Zachmurzenie zmienne, okresowe zamglenia. Widoczność } 4-10 \mathrm{~km} \text {, } \\
\text { przy zamgleniu } 2-3 \mathrm{~km} \text {. Wiatr wschodni, nocą } 3-5 \mathrm{~m} / \mathrm{s} \text {, w ciągu dnia } \\
7-9 \mathrm{~m} / \mathrm{s} \text {, w porywach do } 12 \mathrm{~m} / \mathrm{s} \text {. Temperatura powietrza od } 1-2^{\circ} \mathrm{C} \\
\text { w nocy, } 7-10^{\circ} \mathrm{C} \text { w ciągu dnia. }\end{array}$ \\
\hline
\end{tabular}




\begin{tabular}{|c|c|}
\hline 1 Armia Lotnicza: & $\begin{array}{l}\text { W nocy zachmurzenie } 5-9 / 10 \text { punktów w formach chmur wysokich } \\
\text { i średnich. Zamglenie, widoczność do } 4-10 \mathrm{~km} \text {. W ciągu dnia zachmu- } \\
\text { rzenie } 7-10 / 10 \text { punktów, na średnich i dużych wysokościach. Zamglenia, } \\
\text { widoczność } 4-10 \mathrm{~km} \text {, a przy zamgleniach } 2-3 \mathrm{~km} \text {. }\end{array}$ \\
\hline 33 Armia: & $\begin{array}{l}\text { Zachmurzenie zmienne. Bez opadów. W nocy do całkowitego przejaśnie- } \\
\text { nia. Wiatr wschodni, porywisty, } 3-7 \mathrm{~m} / \mathrm{s} \text {. Temperatura powietrza od } 1^{\circ} \mathrm{C} \\
\text { do } 10^{\circ} \mathrm{C} \text {. }\end{array}$ \\
\hline \multicolumn{2}{|r|}{16 października 1943 r. } \\
\hline Front Zachodni: & $\begin{array}{l}\text { Zachmurzenie duże, wysokość do } 1500 \mathrm{~m} \text { lub więcej. Widoczność } 4-10 \mathrm{~km} \text {, } \\
\text { przy zamgleniu do } 1-3 \mathrm{~km} \text {. Wiatr wschodni } 5-9 \mathrm{~m} / \mathrm{s} \text {. Temperatura } \\
3-6^{\circ} \mathrm{C} \text { w nocy, } 9-11^{\circ} \mathrm{C} \text { za dnia. Na drogach położonych w lasach wystę- } \\
\text { pują miejscowe trudności dla ruchu samochodów. }\end{array}$ \\
\hline 1 Armia Lotnicza: & $\begin{array}{l}\text { W nocy zachmurzenie } 7-10 / 10 \text { punktów, na średnich i dużych wysoko- } \\
\text { ściach. Zamglenia, widoczność do } 4-10 \mathrm{~km} \text {, a przy zamgleniach } 2-3 \mathrm{~km} \text {. } \\
\text { W ciągu dnia zachmurzenie } 8-10 / 10 \text { punktów, na wysokości } 1500- \\
2000 \mathrm{~m} \text {. Widoczność do } 4-10 \mathrm{~km} \text {, a przy wystąpieniu zamglenia } 1-2 \mathrm{~km} \text {. }\end{array}$ \\
\hline 33 Armia: & $\begin{array}{l}\text { Zachmurzenie duże do całkowitego, bez opadów. Wiatr południowo- } \\
\text {-wschodni, porywisty, } 3-5 \mathrm{~m} / \mathrm{s} \text {. Temperatura powietrza w przedziale od } \\
1^{\circ} \mathrm{C} \text { do } 11^{\circ} \mathrm{C} \text {. }\end{array}$ \\
\hline \multicolumn{2}{|r|}{17 października 1943 r. } \\
\hline Front Zachodni: & $\begin{array}{l}\text { Zachmurzenie pełne, wysokość do } 600-1500 \mathrm{~m} \text {, miejscami słaby krótko- } \\
\text { okresowy deszcz, zamglenia. Widoczność } 4-10 \mathrm{~km} \text {, przy zamgleniu do } \\
2-3 \mathrm{~km} \text {. Wiatr południowo-wschodni } 5-10 \mathrm{~m} / \mathrm{s} \text {. Temperatura } 3-7^{\circ} \mathrm{C} \\
\text { w nocy, } 8-11^{\circ} \mathrm{C} \text { za dnia. Na drogach położonych w lasach występują miej- } \\
\text { scowe trudności dla ruchu samochodów. }\end{array}$ \\
\hline 1 Armia Lotnicza: & $\begin{array}{l}\text { W nocy zachmurzenie } 7-10 / 10 \text { punktów, na wysokości } 600-1500 \mathrm{~m} \text {. Wi- } \\
\text { doczność do } 4-10 \mathrm{~km} \text {. W ciągu dnia zachmurzenie } 10 / 10 \text { punktów, na } \\
\text { wysokości } 600-1500 \mathrm{~m} \text {. Widoczność do } 4-10 \mathrm{~km} \text {. }\end{array}$ \\
\hline 33 Armia: & $\begin{array}{l}\text { Pochmurno, bez opadów. Wiatr wschodni, } 2-5 \mathrm{~m} / \mathrm{s} \text {. Temperatura powie- } \\
\text { trza od } 6^{\circ} \mathrm{C} \text { do } 9^{\circ} \mathrm{C} \text {. }\end{array}$ \\
\hline
\end{tabular}

Źródło: Zachowano formę i szyk meldunków. CAMO, Fond 208, Opis 2511, D. 2545, Opierswodki N ${ }^{\circ}$ 469-485 Sztaba FZ, k. 5-94; Fond 290, Opis 0003284, D. 0296, Opierswodki N 272-288 Sztaba 1. WA, k. 140-160; Opierswodki № 471-487 Sztaba 33. Armii, k. 68-92. 


\section{BIBLIOGRAFIA}

\section{Źródła archiwalne}

\section{Bundesarchiv-Militärarchiv in Freiburg im Breisgau}

RH 26-95/36, 38.

RH 26-252/106.

RH 26-337/33.

Centralne Archiwum Ministerstwa Obrony Federacji Rosyjskiej w Podolsku

Fond 208, opis 2511, D. 2408, 2545, 2558, 2588.

Fond 208, opis 2548, D. 74.

Fond 290, opis 0003284, D. 0296.

Fond 388, opis 8712, D. 325, 429, 456.

Centralne Archiwum Wojskowe. Wojskowe Biuro Historyczne im. K. Sosnkowskiego

Dział nr III. Ludowe Wojsko Polskie, sygn.: 7-3, 7-15, 7-546, 7-558, 15-1.

Dział nr IX. Wojskowe Biuro Badań Historycznych, sygn.: 4.44.2, 4.44.8, 4.44.240, 4.44.286, 4.45.38.

\section{Źródła drukowane}

Bąk W., Pieszo i konno, Warszawa 1963.

Berling Z., Przeciw 17 Republice, t. 2, Warszawa 1991.

Dubicki L., Salwy nad Miereja, Warszawa 1980.

Fereniec J., Jak zostatem żotnierzem. Wspomnienia Kościuszkowca, Warszawa 1995.

Marchwicki R., Strzęy wspomnień z Grodna, zestania i wojny, Warszawa 2004.

\section{Opracowania}

Dideńko K., Wojska Inżynieryjno-saperskie LWP 1943-1945 (organizacja i dziatania bojowe), Warszawa 1978.

Durschmied E., Jakpogoda zmieniata losy wojen i świata, Warszawa 2017.

Glantz D.M., Glantz M.E., Battle for Belorussia. The Red Army's Forgotten Campaign of October 1943-April 1944, Kansas 2016. 
Kalinowski L., Meteorologiczne zabezpieczenie dziatań bojowych lotnictwa, „Zeszyty Naukowe Państwowej Wyższej Szkoły Zawodowej im. Witelona w Legnicy” 2017, nr 1, s. $185-195$.

Priamicyn W.N., „Dat w WWS RKKA wysokokwalificyrowannych kadrow mietieorotogow”. Podgotowka wojennych gidromietieorotogow dla Krasnoj armii w 1930-1940-ch godach, „Wojenno-Istoriczeskij Żurnat” („Аать в ВВС РККА высококвалифицированных кадров метеорологов". Подготовка военных гидрометеорологов для Красной армии в 1930-1940-х годах, „Военно-Исторический Журнал”) 2017, N 17, s. 15-21.

Wróblewski R, Bitwa pod Lenino w niemieckich meldunkach, cz. 1 "Militaria XX Wieku” 2010, nr 6 (39), s. 58-69; cz. 2, „Militaria XX Wieku” 2011, nr 2 (41), s. 54-64.

Z zagadnień rozwoju ludowego Wojska Polskiego, red. J. Margules, Warszawa 1964.

\section{Kamil Anduła}

\section{THE IMPACT OF THE WEATHER FACTOR ON THE BATTLE OF $1^{\text {ST }}$ INFANTRY DIVISION TADEUSZ KOŚCIUSZKO AT LENINO}

Summary. The Battle of Lenino took place between October 12 and 17, 1943. During the five days of fighting, the Soviet $33^{\text {rd }}$ Army made a series of attempts to break German defence positions at the Miereja River. During the first two days the Polish $1^{\text {st }}$ Infantry Division was involved. In the polish historiography, the issue of the weather conditions during the Lenino battle has not been a subject of scientific analysis. Based on new sources from German and Russian archives, it became possible to reconstruct the weather conditions during the battle. A new data give a picture of the relatively good weather conditions which gave the advantage for the German side. The command of the $33^{\text {rd }}$ Army were not respond flexibly to changing weather. Besides that before the battle, a group of the Polish deserters revealed the date of the attack. As a result, the Germans gathered strong air force. Taking advantage of the cloudless weather, Luftwaffe gave a strong support to ground forces. It was an important reason of German victory at Lenino.

Keywords: Lenino, weather conditions, the eastern front, Red Army, Luftwaffe 